medRxiv preprint doi: https://doi.org/10.1101/2020.04.29.20085233; this version posted May 5, 2020. The copyright holder for this preprint (which was not certified by peer review) is the author/funder, who has granted medRxiv a license to display the preprint in perpetuity.

All rights reserved. No reuse allowed without permission.

\title{
The Utility of rRT-PCR in Diagnosis and Assessment of Case-fatality rates of COVID-19 In the Iranian Population - Positive Test Results are a Marker for Illness Severity
}

Authors:

Ghasem Janbabaei MD ${ }^{1,2}$, Eric J. Brandt, MD ${ }^{3,4}$, Reza Golpira, MD MPH ${ }^{5}$, Alireza Raeisi MD ${ }^{6,7}$, Jafar

Sadegh Tabrizi MD, Ph.D ${ }^{8,9}$, Hamid Reza Safikhani MD ${ }^{10}$, Mohammad Taghi Talebian, MD $^{11}$, Siamak Mirab Samiee $\mathrm{PhD}^{12}$, Alireza Biglar $\mathrm{PhD}^{13}$, Reza Malekzadeh MD*14,15, Arya Mani MD*, 4,16,17

Affiliations:

${ }^{1}$ Curative Affairs Deputy, Ministry of Health and Medical Education, Tehran, Iran.

${ }^{2}$ Gastrointestinal Cancer Research Center, Mazandaran University of Medical Sciences, Sari, Iran.

${ }^{3}$ National Clinician Scholars Program, Yale University School of Medicine, New Haven, CT

${ }^{4}$ Section of Cardiovascular Medicine, Department of Internal Medicine, Yale University School of Medicine, New Haven, CT

${ }^{5}$ Rajaie Cardiovascular Medical and Research center, Iran University of Medical Sciences, Tehran, Iran.

${ }^{6}$ School of Medicine, Shiraz University of Medical Sciences, Shiraz, Iran.

${ }^{7}$ Health Deputy, Ministry of Health and Medical Education, Tehran, Iran.

${ }^{8}$ Health Services Management Research center, School of Health Management and Medical Informatics,

Tabriz university of Medical sciences, Tabriz, Iran.

${ }^{9}$ Primary Health Care Network Management Center, Ministry of Health and Medical Education, Tehran, Iran

${ }^{10}$ Information Technology Office, Ministry of Health and Medical Education, Tehran, Iran

${ }^{11}$ Department of Emergency Medicine, Tehran University of Medical Sciences, Tehran, Iran

${ }^{12}$ National Reference Laboratories. Ministry of Health, Tehran, Iran

${ }^{13}$ Pasteur Institute of Iran, Tehran, Iran

${ }^{14}$ Digestive Disease Research Center, Digestive Disease Institute, Shariati Hospital, Tehran University of Medical Sciences Tehran, Iran.

${ }^{15}$ Deputy for Research and Innovation, Ministry of Health and Medical Education, Tehran Iran

${ }^{16}$ Yale Cardiovascular Research Center, Department of Medicine, Yale University School of Medicine, Yale university, New Haven, CT, USA.

${ }^{17}$ Department of Genetics, Yale University School of Medicine, Yale University, New Haven, CT.

*Contributed equally, co-senior authorship

Corresponding author:

Arya Mani

Email: Arya.Mani@yale.edu

Address:

Department of Medicine \& Genetics

Yale University

300 George Street, New Haven, CT 06520

Tel: (203)737-2837

Fax: (203)785-7560

Funding:

This publication was made possible by CTSA Grant Number TL1 TR001864 from the National Center for Advancing Translational Science (NCATS), a component of the National Institutes of Health (NIH). Its contents are solely the responsibility of the authors and do not necessarily represent the official view of NIH.

Conflicts of interest/competing interests: $\mathrm{n} / \mathrm{a}$

Availability of data and material: aggregated data tables for analyses available upon request

Code availability: n/a 
medRxiv preprint doi: https://doi.org/10.1101/2020.04.29.20085233; this version posted May 5, 2020. The copyright holder for this preprint

(which was not certified by peer review) is the author/funder, who has granted medRxiv a license to display the preprint in perpetuity.

All rights reserved. No reuse allowed without permission.

\begin{abstract}
The utility of PCR-based testing in characterizing patients with COVID-19 and the severity of their disease remains unknown. We performed an observational study among patients presenting to hospitals in Iran who were tested for 2019-nCoV viral RNA by rRT-PCR between the fourth week of February 2020 to the fourth week of March 2020. Frequency of symptoms, comorbidities, intubation, and mortality rates were compared between COVID-19 positive vs. negative patients. 96103 patients were tested from 879 hospitals. 18754 (19.5\%) tested positive for COVID-19. Positive testing was more frequent in those 50 years or older. The prevalence of cough $(54.5 \%$ vs. $49.7 \%)$, fever ( $49.5 \%$ vs. $44.7 \%$ ), and respiratory distress $(43.0 \%$ vs. $39.0 \%)$ but not hypoxia ( $46.9 \%$ vs. $56.7 \%$ ) was higher in COVID-19 positive vs. negative patients ( $<<0.001$ for all). More patients had cardiovascular diseases $(10.6 \%$ vs. $9.5 \%, \mathrm{p}<0.001)$ and type 2 diabetes mellitus $(10.8 \%$ vs. $8.7 \%, \mathrm{p}<0.001)$ among COVID-19 positive vs. negative patients. There were fewer patients with cancer $(1.1 \%$, vs. $1.4 \%, \mathrm{p}<0.001)$, asthma $(1.9 \%$ vs. $2.5 \%, \mathrm{p}<0.001)$, or pregnant $(0.4 \%$ vs. $0.6 \%,=0.001)$ in COVID-19 positive vs. negative groups. COVID-19 positive vs. negative patients required more intubation ( $7.7 \%$ vs. $5.2 \%, \mathrm{p}<0.001)$ and had higher mortality ( $14.6 \%$ vs. $6.3 \%, \mathrm{p}<0.001)$. Odds ratios for death of positive vs negative patients range from 2.01 to 3.10 across all age groups. In conclusion, COVID-19 testpositive vs. test-negative patients had more severe symptoms and comorbidities, required higher intubation, and had higher mortality. rRT-PCR positive result provided diagnosis and a marker of disease severity in Iranians.
\end{abstract}

\title{
KEYWORDS
}

Iran, COVID-19, PCR, testing, pandemic 
medRxiv preprint doi: https://doi.org/10.1101/2020.04.29.20085233; this version posted May 5, 2020. The copyright holder for this preprint

\section{IN TRODUCTION}

Following the spread of the 2019 novel coronavirus (SARS-COV-2) in Asia, the first documented case of COVID-19 in Iran was made on February 12, 2020 in the City of Qom. The Deputy for Health and Curative Affairs at the Iranian Ministry of Health and Medical Education (MOHME) responded urgently by compiling World Health Organization (WHO) guidelines for COVID-19 prevention, diagnosis and treatment. The MOHME designed and launched its National Mobilization Plan Against COVID-19 in a collaborative effort between the Ministry's Deputy for Health and Curative Affairs, military organizations, non-governmental organizations (NGOs), and other volunteers.

Relying on a centralized health care system, the health-care authorities of Iran initiated a coordinated effort to implement preventive measures and to diagnose and treat patients with COVID-19. Close to 1,000 comprehensive health centers functioning 16 and 24 hours per day, seven days of the week were designated to provide specific COVID-19 services according to a standard protocol. Immediate in-person education was provided to first line responders throughout the country in preparation for the spread of the coronavirus. Instruction for screening, diagnosis and treatment of COVID-19 was provided through widely available electronic National Health care system. An interactive website linked to medical records was designed and made widely accessible to the public for self-screening of the general population. The website can be accessed using national identification number and birth date and provides medical advice according to individual's responses to specific disease-related questions.

In this process, it soon became apparent that without an efficient tool for the diagnosis there is a little to no chance to harness this fatal pandemic. Real-time reverse transcriptase-polymerase chain reaction (rRTPCR) of nasopharyngeal swabs is widely used to confirm the clinical diagnosis, but significant false negative results have created concerns about its utility[1]. Additionally, it is unclear what presenting symptoms and comorbidities are more common amongst COVID-19 positive vs. negative patients.

Therefore, we completed a study to compare the frequency of presenting symptoms, comorbidities, mechanical ventilation, or death between COVID-19 positive and negative patients hospitalized with acute respiratory illness.

\section{METHODS}

\section{Study population}

We performed an observational study using data collected from patient registry records of individual hospitals in 879 designated hospitals from all 31 provinces of Iran between the fourth week of February to the fourth week of March.

\section{Case identification}

As of the fourth week of March 2020, millions of individuals were screened either by phone or by self-evaluation using interactive websites. Screening including questions about specific symptoms, including fever, chills, cough, sore throat, respiratory distress, and their potential contact with individuals with suspected COVID-19 infection. All individuals were provided with information for prevention, modes of disease transmission and means of personal protection. Individuals identified as possible COVID-19 cases were referred to specialized health-care centers for COVID-19 testing. Simultaneously, these centers received a text message to contact the suspected patients for the initiation of diagnosis, home therapy, and subsequent 
medRxiv preprint doi: https://doi.org/10.1101/2020.04.29.20085233; this version posted May 5, 2020. The copyright holder for this preprint

follow-ups or referral to specialized centers. Those deemed as high risk for acquiring the disease, including those with T2D and hypertension, obesity, immunodeficiency, malignant disorders undergoing immune suppressive therapy, and pregnant women were prioritized. At the specialized health-care centers patients with severe respiratory distress and/or oxygen saturation below 93\%, reduced levels of consciousness, or intractable cough were sent to COVID-19 referral hospitals for hospitalization. All hospitalized COVID-19 positive patients were put on a triple therapy treatment protocol that included Hydroxychloroquine (400 mg loading dose, followed by $200 \mathrm{mg}$ twice a day), Lopinavir-Ritonavir (Kaletra), and Ribavirin for 2 weeks. Hemodynamically stable patients with mild symptoms were placed on Hydroxychloroquine and discharged to home quarantine. All data were entered into a computerized database at the National MOH COVID-19 Database.

Assay

Diagnosis of COVID-19 was made based on the presence of viral RNA by real-time reverse-transcriptasepolymerase-chain-reaction (rRT-PCR) assays in accordance with the protocol established by the WHO[2] at the Pasteur Institute of Iran and at the National Reference Laboratories.

\section{Study design, definitions, and diagnosis}

Data extracted includes clinical symptoms or signs, comorbidities, ventilator use, and mortality.

Radiologic assessments included computed tomography (CT) of the chest, which were not available at the time of preparation of this manuscript.

Symptoms or signs included cough, fever, respiratory distress, hypoxia, myalgia, and reduced level of consciousness. Fever was defined as a forehead temperature $\geq 37.6^{\circ} \mathrm{C}$. Hypoxia was defined as oxygen saturation $\left(\mathrm{PO}^{2}\right)<93 \%$. Reduced level of consciousness was defined as reduced levels of responsiveness to verbal and noxious stimuli from obtundation to coma. Presence of other symptoms, including shivering, loss of smell (anosmia) and taste (ageusia), abdominal pain, nausea, and vomiting were documented by some centers but not systematically inquired.

Comorbidities include Type 2 diabetes mellitus(T2D), cardiovascular disease, acute kidney injury, asthma, currently pregnant, chronic renal failure, cancer, and history of HIV/AIDS. Type 2 diabetes mellitus (T2D) was defined as fasting blood glucose $\geq 126 \mathrm{mg} / \mathrm{dl}$ or use of oral glycemic mediations or insulin. Cardiovascular disease was defined as history of known coronary artery disease by catheterization, history of congestive heart failure according to diagnosis codes, or ejection fraction less than $45 \%$. Acute kidney injury was defined as a drop in glomerular filtration rate (GFR) of $25 \%$. Chronic kidney disease was defined as GFR $<60 \mathrm{~mL} / \mathrm{min} / 1.73 \mathrm{~m}^{2}$. Cancer is defined as active malignancy. Data on the number HIV positive or cancer patients on active therapy is not available.

Intubation was defined as requiring use of a ventilator at any time during hospitalization. Mortality was defined by in-hospital death.

Study oversight

The study was initiated by The Deputy for Health and Curative affairs at the Iranian Ministry of Health and Medical Education (MOHME) and approved by the institutional review boards of the participating hospitals (http://ethics.research.ac.ir/IndexEn.php). Data collection and analysis was supervised by the Department for 
medRxiv preprint doi: https://doi.org/10.1101/2020.04.29.20085233; this version posted May 5, 2020. The copyright holder for this preprint (which was not certified by peer review) is the author/funder, who has granted medRxiv a license to display the preprint in perpetuity. All rights reserved. No reuse allowed without permission.

Research and Innovation Ministry of Health and Medical Education, Tehran, Iran. The authors have reviewed the data and the manuscript and attest to the accuracy of the data and the adherence to the protocols of the NEJM.org. Statistical Analysis

Comparisons between COVID-19 positive to negative patients were made using odds ratios. Cells containing $<5$ counts were excluded from odds ratio calculations. Comparisons between groups were made using $\chi^{2}$ test or Fisher Exact test (when any cell contained $\leq 10$ samples). A 2-tailed p-value $<0.05$ was considered statistically significant. We conducted data analysis March through April 2020. Data were analyzed using Excel v16.35 (Microsoft) and Stata 16 (StataCorp, LLC).

\section{RESULTS}

\section{Population Characteristics}

A total of 96103 individuals were hospitalized with acute respiratory illness. 18754 (19.5\%) tested positive for SARS-CoV-2 by rRT-PC (Table 1; see Supplementary Table 1 for cases by province). The mean age of COVID-19 positive and COVID-19 negative patients were 55.2 and 50.9 years, respectively. There were more men than women among COVID-19 positive patients (61\% vs. 39\%).

Among children under 10 years and 10 to 20 years, 3.6\% and 6.8\% were COVID-19 positive, respectively (Table 1). The percent positive increased to $11.3 \%$ and $17.4 \%$ in subjects $20-30$ and $30-40$ years old, respectively. Above age 40, positive results were present in about $20 \%$ of cases (range: $20.8 \%$ to $22.3 \%$ ).

A total of $52666(54.8 \%)$ of the 96103 hospitalized patients were discharged home. 10277 (19.5\%) of these 52666 patients were COVID-19 positive (Supplementary Table 1).

\section{Symptoms and signs}

COVID-19 positive patients showed higher incidence of cough, fever, respiratory distress, and myalgia (Table 2, Fig. 1). Whereas, there was a lower incidence of hypoxia and reduced level of consciousness. Directionality of symptoms was similar across all age groups, although differences between COVID-19 positive vs. negative patients were less apparent in the age groups $<20$ years old (Fig. 1). Additionally, as age increased the frequency of cough, fever, hypoxia decreased while respiratory distress tended to increase (Supplementary Table 2).

\section{Comorbidities}

T2D and cardiovascular diseases were the two major comorbidities more prevalent among COVID-19 positive compared to COVID-19 negative patients with acute respiratory disease (Table 2. Fig. 1, Supplementary Table 3). There were no significant differences in the rate of HIV/AIDS, chronic kidney disease, chronic anemia, acute kidney injury, hemodialysis treatment and congenital diseases between the two groups. Strikingly there were fewer patients with asthma, cancer, or pregnancy in COVID-19 positive compared to COVID-19 negative patients (Table 2. Fig. 1).

\section{Intubation/ventilator use}

A total of 1450 (7.7\%) COVID-19 positive and 3999 (5.2\%) COVID-19 negative individuals received ventilatory support $(\mathrm{p}<0.001)$ (Supplementary Table 4), which translates to an absolute difference of $26 \%$ (Table 2, Fig 2). There were higher number of COVID-19 positive vs. negative patients requiring ventilatory support in all age groups.

\section{Mortality}


medRxiv preprint doi: https://doi.org/10.1101/2020.04.29.20085233; this version posted May 5, 2020. The copyright holder for this preprint

Frequency of death was higher among COVID-19 positive ( $\mathrm{n}=2740,14.6 \%)$ vs. COVID-19 negative patients $(n=4898,6.3 \%)$ (Table 3). The odds ratios for death for COVID-19 positive vs. negative patients was higher across all age groups (Table 3 and Fig. 2).

\section{DIS CUSSION}

An urgent collaborative response from multiple Iranian agencies resulted in a rapid symptom screening of a large portion of the country's population. Among these about 100,000 cases of concern were identified, about 1 -in-5 of whom were tested positive for COVID-19 with rRT-PCR. Notably, cases that were COVID-19 positive were more likely to have cough, fever, respiratory distress, and myalgia, but lower level of hypoxia. Positive cases were also more likely to have cardiovascular disease or T2D but less likely to have asthma, cancer, or be pregnant. COVID-19 testing was associated with increased odds for intubation of 1.5 and death of 2.5 times compared to those with negative testing.

The pandemic of COVID-19 has caused devastation in many countries and continues to spread throughout the world. The early diagnosis of the disease in the population is the most efficient way to prevent further spread of this disease and is a necessary step toward its eradication. To this date several types of testing have been generated but none have been perfect. Real-time reverse transcriptase-polymerase chain reaction (rRT-PCR) of nasopharyngeal swabs, targeting the open reading frame $1 a b$ gene of SARS-CoV-2 have been widely used to confirm the clinical diagnosis[3]. Unfortunately, PCR amplification of virus RNA from nasal swabs have shown low sensitivities in detecting viral infection[1]. While Bronchoalveolar lavage fluid specimens have shown greater than $90 \%$ Sensitivity in detecting viral RNA by rRT-PCR rates (14 of 15; 93\%), the method is not practical in normal settings and is associated with high risk of disease transmission to the health care providers. At this point rRT-PCR of the virus RNA from nasal swabs remain the most practical way for diagnosis of the disease. Therefore, we examined its utility in disease diagnosis and as a marker of disease severity in more than 90,000 suspicious cases in Iran. By comparing signs and symptoms and complications of COVID-19 test positive patients with those negative for the test we demonstrate here the utility of this test as a marker of disease severity.

Those positive for COVID-19 in our study had differential symptoms compared to COVID-19 negative cases. One would expect that COVID-19 patient would be more likely to present with all viral type symptoms. This was mostly true in our study. However, in opposition to previous reports[4], oxygen desaturation was not more common among COVID-19 positive vs. negative patients. Instead, other clinical findings of fever, cough, and respiratory distress were associated with positive testing. This suggests that hypoxia should not be the only symptom that increases clinician suspicion for COVID-19

Those positive for COVID-19 in our study were more likely to have cardiovascular disease, diabetes, and had higher rates of intubation and death compared to COVID-19 test-negative patients. This may reflect greater virus replication and higher viral load in severe cases as previously shown[5], which expectedly results in easier detection of viral genome and increased disease severity. Interesting, the rates of intubation and death were higher in COVID-19 test-positive vs. test-negative patients in all age groups, including children and adolescents. Earlier studies from China had shown higher rate of disease and its complications among patients older than 65[6]. Our data indicates that COVID-19 has disproportionately affected young individuals in Iran 
medRxiv preprint doi: https://doi.org/10.1101/2020.04.29.20085233; this version posted May 5, 2020. The copyright holder for this preprint

compared to other countries. This may reflect the unique population structure of Iran, which is significantly younger compared to most other countries (World Population Prospects 2019,

https://population.un.org/wpp/). In addition, limited access to study drugs and modern therapies due to the economic sanction may have partially accounted for the increased death rate in the younger generations [7]. High prevalence of T2D and metabolic syndrome in Iranians youth may have also increased susceptibility to disease and its complications.[8] Accordingly, there were more patients with T2D in COVID-19 test-positive vs. negative groups. An association between T2D and poor outcome in patients with COVID-19 has been previously reported $[9,10]$.

Our data also identifies cardiovascular disease as a comorbidity that increases the susceptibility to COVID-19. One intriguing finding of our study is the reduced number of patients that are COVID-19 test positive among those with HIV/AIDS, asthma, cancer, and pregnant women. Based on data from the trials of antiretroviral therapy in Adults Hospitalized patients with severe COVID-19[4] it is unlikely that HIV patients benefited from antiretroviral drugs. It has been hypothesized that a subgroup of patients with severe COVID19 might suffer from cytokine storm [11]. It is, therefore, more likely that impaired immune system in HIV patients reduces the frequency of cytokine storm. Alternatively, the lower disease rates among higher risk groups is due to a lower threshold for testing in these populations or an increased adherence to social distance among those with known immunocompromising diseases. Information on what percentage of the patients with cancer were being treated with immune suppressive therapy is therefore critical but lacking at this point. In addition, data on lymphocyte count, plasma CRP, IL-6 and TNF was not available when our data were compiled and is being actively collected. Undoubtedly, establishing as to whether cytokine storm underlies disease pathogenesis in severe COVID-19 can have important therapeutic implications.

As with many other countries in the world, lack of experience has undoubtedly led to shortcomings and errors in facing this pandemic. However, considering the structure of the society that promotes high social contacts and many public events that have occurred since the begin of the COVID-19 pandemic mortality in Iran has been significantly lower than anticipated. One possible factor that has limited the number of deaths is the existence of a centralized health care system that has allowed health care authorities to allocate more hospitals and beds and issue uniform guidelines for therapy and use of resources for COVID-19 patients. Accordingly, in contrast to many other countries no shortage of ventilators in Iran has been encountered.

Our study has limitations that confines interpretation. Our data does not include the chest CT-scan results of patients with acute respiratory illness. Access to this data given the probability of false negative PCR results is particularly important. Additionally, the data analyzed in our study were aggregated and hence adjustment for multiple covariates due to lack of access to patient level data could not be carried out. Nevertheless, the higher rate of mortality in patients tested positive vs. those tested negatives suggests that the PCR-based testing has been a relatively suitable method for the screening of high-risk patients.

\section{CONCLUSION}

Our experience suggests that use of rRT-PCR diagnostic method allows better identification of high-risk patients and early utilization of advanced therapeutic measures. Lessons from Iranian experience of COVID-19 
medRxiv preprint doi: https://doi.org/10.1101/2020.04.29.20085233; this version posted May 5, 2020. The copyright holder for this preprint (which was not certified by peer review) is the author/funder, who has granted medRxiv a license to display the preprint in perpetuity.

All rights reserved. No reuse allowed without permission.

should hopefully assist other countries in reducing the fatalities and the economic burden of this pandemic and facilitate preparedness for future pandemics. 
medRxiv preprint doi: https://doi.org/10.1101/2020.04.29.20085233; this version posted May 5, 2020. The copyright holder for this preprint (which was not certified by peer review) is the author/funder, who has granted medRxiv a license to display the preprint in perpetuity.

All rights reserved. No reuse allowed without permission.

\section{ACKNOWLEDGEMENTS}

We would like to acknowledge all clinicians, nurses, and healthcare workers in 879 hospitals in Iran for their unlimited devotion to the care of Iranian COVID-19 patients while sacrificing their health and lives. We like to thank Dr. Saeed Namaki, the Minister of health for his leadership and dedication to the care of COVID-19 patients and Drs. Tayeb Ghadimi, and. Abdolkhalegh Keshavarzi, Mr. Reza Mahmoudi Lamouki, and Bagherzadeh for their help with the data preparation, management and analysis.

\section{REFERENCES}

1. Wang, W., et al., Detection of SARS-CoV-2 in Different Types of Clinical Specimens. JAMA, 2020.

\section{Organization., W.H., Coronavirus}

disease (COVID-19) technical guidance:

laboratory testing for 2019-nCoV in

humans. https://www .who .int/ emergencies/diseases/ novel -coronavirus-2019/technical-guidance/ laboratory -guidance).

3. Wang, D., et al., Clinical Characteristics of 138 Hospitalized Patients With 2019 Novel Coronavirus-Infected Pneumonia in Wuhan, China. JAMA, 2020.

4. Cao, B., et al., A Trial of Lopinavir-Ritonavir in Adults Hospitalized with Severe Covid-19. N Engl J Med, 2020.

5. Liu, Y., et al., Viral dynamics in mild and severe cases of COVID-19. Lancet Infect Dis, 2020.

6. Li, Q., et al., Early Transmission Dynamics in Wuhan, China, of Novel Coronavirus-Infected Pneumonia. N Engl J Med, 2020. 382(13): p. 1199-1207.

7. Aloosh, M., A. Salavati, and A. Aloosh, Economic sanctions threaten population health: the case of Iran. Public Health, 2019. 169: p. 10-13.

8. Khashayar, P., et al., Metabolic Syndrome and Cardiovascular Risk Factors in a National Sample of Adolescent Population in the Middle East and North Africa: The CASPIAN III Study. Int J Endocrinol, 2013. 2013: p. 702095. 
medRxiv preprint doi: https://doi.org/10.1101/2020.04.29.20085233; this version posted May 5, 2020. The copyright holder for this preprint (which was not certified by peer review) is the author/funder, who has granted medRxiv a license to display the preprint in perpetuity.

All rights reserved. No reuse allowed without permission.

9. Yang, X., et al., Clinical course and outcomes of critically ill patients with SARS-CoV-2 pneumonia in Wuhan, China: a single-centered, retrospective, observational study. Lancet Respir Med, 2020.

10. Guan, W.J., et al., Clinical Characteristics of Coronavirus Disease 2019 in China. N Engl J Med, 2020.

11. Mehta, P., et al., COVID-19: consider cytokine storm syndromes and immunosuppression. Lancet, 2020. 395(10229): p. 1033-1034. 
medRxiv preprint doi: https://doi.org/10.1101/2020.04.29.20085233; this version posted May 5, 2020. The copyright holder for this preprint (which was not certified by peer review) is the author/funder, who has granted medRxiv a license to display the preprint in perpetuity.

All rights reserved. No reuse allowed without permission.

Table1: Total number and percent of COVID-19 positive patients in different age groups

\begin{tabular}{|lccc|}
\hline Age Groups & $\mathbf{n}$ & COVID-19 Positive & \% \\
\hline 0 to 10 years & 2224 & 81 & $3.6 \%$ \\
\hline 10 to 20 years & 2094 & 145 & $6.9 \%$ \\
\hline 20 to 30 years & 7391 & 836 & $11.3 \%$ \\
\hline 30 to 40 years & 14679 & 2553 & $17.4 \%$ \\
\hline 40 to 50 years & 15778 & 3274 & $20.8 \%$ \\
\hline 50 to 60 years & 17422 & 3878 & $22.3 \%$ \\
\hline 60 to 70 years & 16544 & 3664 & $22.1 \%$ \\
\hline 70 to 80 years & 11500 & 2543 & $22.1 \%$ \\
\hline 80 years and over & 8471 & 1779 & $21.0 \%$ \\
\hline Overall & 96103 & 18754 & $19.5 \%$ \\
\hline
\end{tabular}


Table 2: Frequency of presenting symptoms and signs, comorbidities, intubation, and death in COVID-19 positive vs negative patients

\begin{tabular}{|c|c|c|}
\hline $\begin{array}{c}\text { Prevalence of } \\
\text { covariate } \\
\text { among }\end{array}$ & $\begin{array}{c}\text { Prevalence of } \\
\text { covariate } \\
\text { among }\end{array}$ & $\begin{array}{l}\% \text { among those } \\
\text { reporting } \\
\text { covariates with }\end{array}$ \\
\hline COVID-19 & COVID-19 & positive COVID- \\
\hline Positive & Negative & 19 result \\
\hline
\end{tabular}

\begin{tabular}{|c|c|c|c|}
\hline \multicolumn{4}{|l|}{ Symptoms and signs } \\
\hline Cough & $54.5 \%$ & $49.7 \%$ & $21.0 \%$ \\
\hline Fever & $49.5 \%$ & $44.7 \%$ & $21.2 \%$ \\
\hline PO2 $<93 \%$ & $46.9 \%$ & $56.7 \%$ & $16.7 \%$ \\
\hline Reduced levels of Consciousness & $2.8 \%$ & $3.6 \%$ & $16.0 \%$ \\
\hline Respiratory Distress & $43.0 \%$ & $39.0 \%$ & $21.1 \%$ \\
\hline Myalgia & $20.9 \%$ & $19.6 \%$ & $20.6 \%$ \\
\hline
\end{tabular}

\section{Comorbidities}

\begin{tabular}{|c|c|c|c|}
\hline Age (years) & 55.2 & 50.9 & \\
\hline Asthma & $1.9 \%$ & $2.5 \%$ & $16.0 \%$ \\
\hline Pregnant & $0.4 \%$ & $0.6 \%$ & $13.7 \%$ \\
\hline Cardiovascular Disease & $10.6 \%$ & $9.5 \%$ & $21.3 \%$ \\
\hline Chronic kidney disease & $0.4 \%$ & $0.4 \%$ & $19.6 \%$ \\
\hline Chronic Anemia & $0.7 \%$ & $0.7 \%$ & $19.8 \%$ \\
\hline Acute Kidney Injury & $1.6 \%$ & $1.6 \%$ & $19.4 \%$ \\
\hline Cancer & $1.1 \%$ & $1.4 \%$ & $15.3 \%$ \\
\hline Type 2 Diabetes Mellitus & $10.8 \%$ & $8.7 \%$ & $23.0 \%$ \\
\hline Chronic Neurologic Disease & $0.9 \%$ & $1.0 \%$ & $18.1 \%$ \\
\hline AIDS/HIV & $0.0 \%$ & $0.1 \%$ & $12.0 \%$ \\
\hline Congenital Diseases & $0.3 \%$ & $0.3 \%$ & $21.3 \%$ \\
\hline Hemodialysis & $0.7 \%$ & $0.7 \%$ & $18.1 \%$ \\
\hline \multicolumn{4}{|l|}{ Ventilator Need } \\
\hline Intubation & $7.7 \%$ & $5.2 \%$ & $26.6 \%$ \\
\hline \multicolumn{4}{|l|}{ Outcome } \\
\hline Death & $14.6 \%$ & $6.3 \%$ & $35.9 \%$ \\
\hline
\end{tabular}


Table 3 Death counts and rate by COVID-19 testing results.

\begin{tabular}{|c|c|c|c|c|c|c|c|c|}
\hline $\begin{array}{l}\text { Age } \\
\text { Groups }\end{array}$ & $\begin{array}{c}\text { Death } \\
\text { among } \\
\text { COVID } \\
\text { positive } \\
\text { (n) }\end{array}$ & $\begin{array}{c}\text { Death } \\
\text { among } \\
\text { COVID } \\
\text { negative } \\
\text { (n) }\end{array}$ & $\begin{array}{c}\text { Death } \\
\text { rate } \\
\text { among } \\
\text { positive } \\
\text { cases }\end{array}$ & $\begin{array}{c}\text { Death } \\
\text { rate } \\
\text { among } \\
\text { negative } \\
\text { cases }\end{array}$ & $\begin{array}{c}\text { Positive } \\
\text { cases } \\
\text { among } \\
\text { deaths }\end{array}$ & OR $(95 \%$ CI $)$ & $\begin{array}{c}\text { p- } \\
\text { value* }\end{array}$ & $\begin{array}{l}* \text { Note } \\
\text { where } \\
\text { there } \\
\text { were }\end{array}$ \\
\hline$<10$ years & 5 & 51 & $6.2 \%$ & $2.4 \%$ & $8.9 \%$ & $\begin{array}{c}2.70(1.05 \\
6.95)\end{array}$ & $0.051^{*}$ & $\begin{array}{l}\text { cells } \\
\text { with }\end{array}$ \\
\hline $\begin{array}{l}10 \text { to } 20 \\
\text { years }\end{array}$ & 8 & 36 & $5.5 \%$ & $1.8 \%$ & $18.2 \%$ & $\begin{array}{c}3.10(1.41 \\
6.81)\end{array}$ & $0.009 *$ & $\begin{array}{l}<10 \\
\text { counts }\end{array}$ \\
\hline $\begin{array}{l}20 \text { to } 30 \\
\text { years }\end{array}$ & 30 & 84 & $3.6 \%$ & $1.3 \%$ & $26.3 \%$ & $\begin{array}{c}2.86(1.88 \\
4.37)\end{array}$ & $<0.001$ & $\begin{array}{l}\text { the } \\
\text { Fisher }\end{array}$ \\
\hline $\begin{array}{l}30 \text { to } 40 \\
\text { years }\end{array}$ & 93 & 203 & $3.6 \%$ & $1.7 \%$ & $31.4 \%$ & $\begin{array}{c}2.22(1.73 \\
2.85)\end{array}$ & $<0.001$ & $\begin{array}{l}\text { Exact } \\
\text { test }\end{array}$ \\
\hline $\begin{array}{l}40 \text { to } 50 \\
\text { years }\end{array}$ & 205 & 402 & $6.3 \%$ & $3.2 \%$ & $33.8 \%$ & $\begin{array}{c}2.01(1.69 \\
2.39)\end{array}$ & $<0.001$ & $\begin{array}{l}\text { was } \\
\text { used, }\end{array}$ \\
\hline $\begin{array}{l}50 \text { to } 60 \\
\text { years }\end{array}$ & 427 & 712 & $11.0 \%$ & $5.3 \%$ & $37.5 \%$ & $\begin{array}{c}2.23(1.97 \\
2.53)\end{array}$ & $<0.001$ & $\begin{array}{l}\text { all } \\
\text { other }\end{array}$ \\
\hline $\begin{array}{l}60 \text { to } 70 \\
\text { years }\end{array}$ & 661 & 1146 & $18.0 \%$ & $8.9 \%$ & $36.6 \%$ & $\begin{array}{c}2.25(2.03 \\
2.50)\end{array}$ & $<0.001$ & $\begin{array}{l}\text { tests } \\
\text { are } \chi^{2}\end{array}$ \\
\hline $\begin{array}{l}70 \text { to } 80 \\
\text { years }\end{array}$ & 681 & 1144 & $26.8 \%$ & $12.8 \%$ & $37.3 \%$ & $\begin{array}{c}2.50(2.24 \\
2.78)\end{array}$ & $<0.001$ & \\
\hline$>80$ years & 630 & 1120 & $35.4 \%$ & $16.7 \%$ & $36.0 \%$ & $\begin{array}{c}2.73(2.43 \\
3.06)\end{array}$ & $<0.001$ & \\
\hline All ages & 2740 & 4898 & $14.6 \%$ & $6.3 \%$ & $35.9 \%$ & $\begin{array}{c}2.53(2.41 \\
2.66)\end{array}$ & $<0.001$ & \\
\hline
\end{tabular}


medRxiv preprint doi: https://doi.org/10.1101/2020.04.29.20085233; this version posted May 5, 2020. The copyright holder for this preprint (which was not certified by peer review) is the author/funder, who has granted medRxiv a license to display the preprint in perpetuity.

All rights reserved. No reuse allowed without permission.

Figure 1: Overall frequency and Odds ratios by age for overall symptoms, signs, and comorbidities between COVID-19 positive and negative individuals hospitalized for acute respiratory illnesses

A: Comparison of overall symptoms and signs between COVID-19 positive and negative individuals hospitalized for acute respiratory illnesses

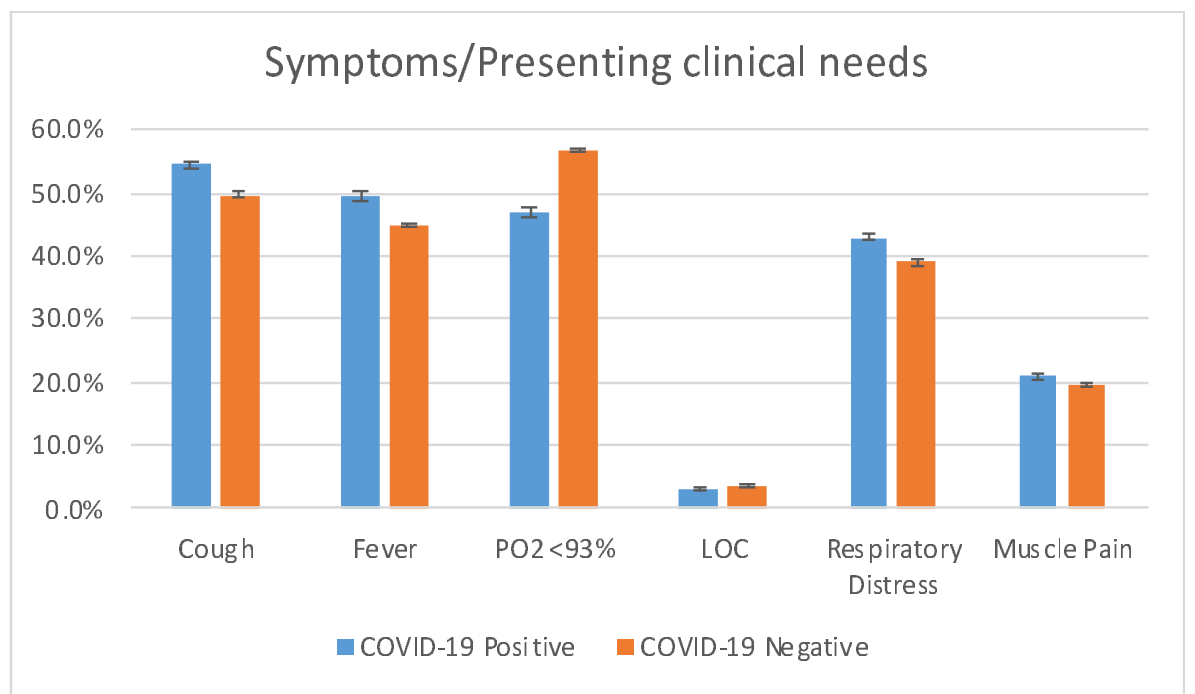

B: Comparison of overall comorbidities at the time of presentation between COVID-19 positive and negative individuals hospitalized for acute respiratory illnesses

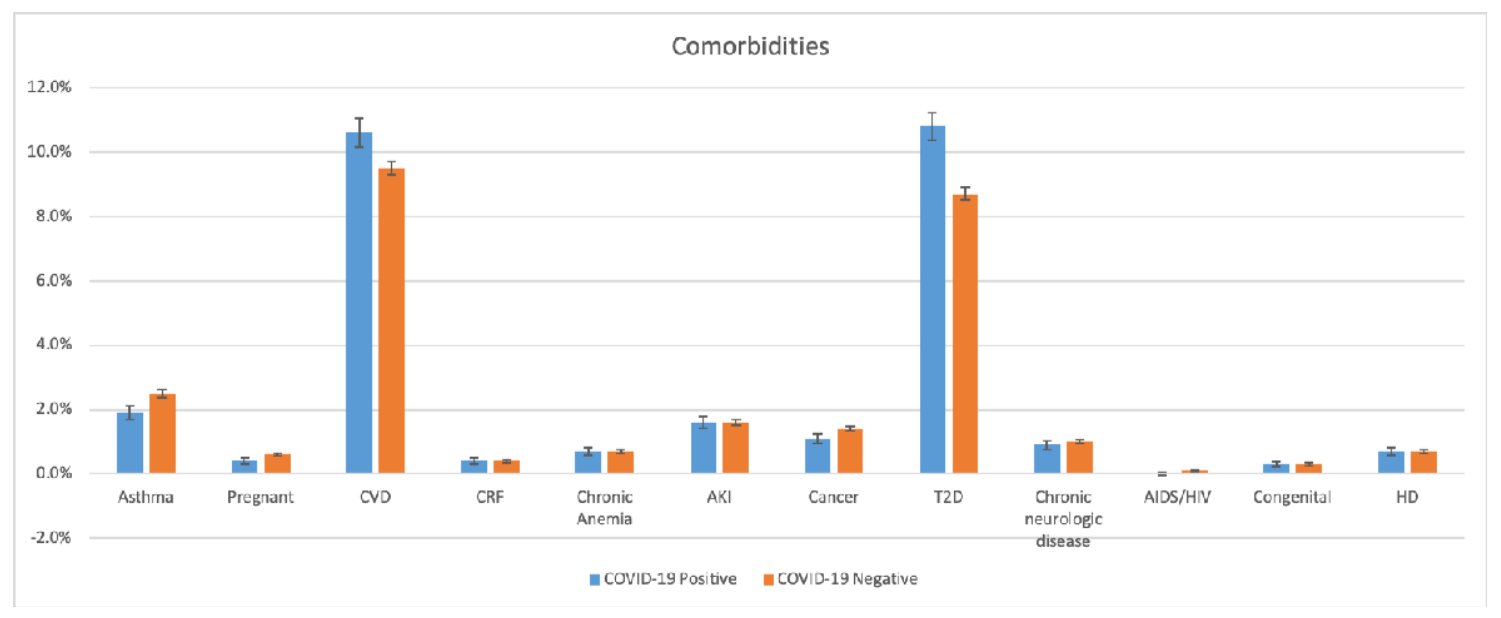


medRxiv preprint doi: https://doi.org/10.1101/2020.04.29.20085233; this version posted May 5, 2020. The copyright holder for this preprint (which was not certified by peer review) is the author/funder, who has granted medRxiv a license to display the preprint in perpetuity. All rights reserved. No reuse allowed without permission.

C: Odds ratio for COVID-19 positive vs negative patients of presenting symptoms and signs by age groups and

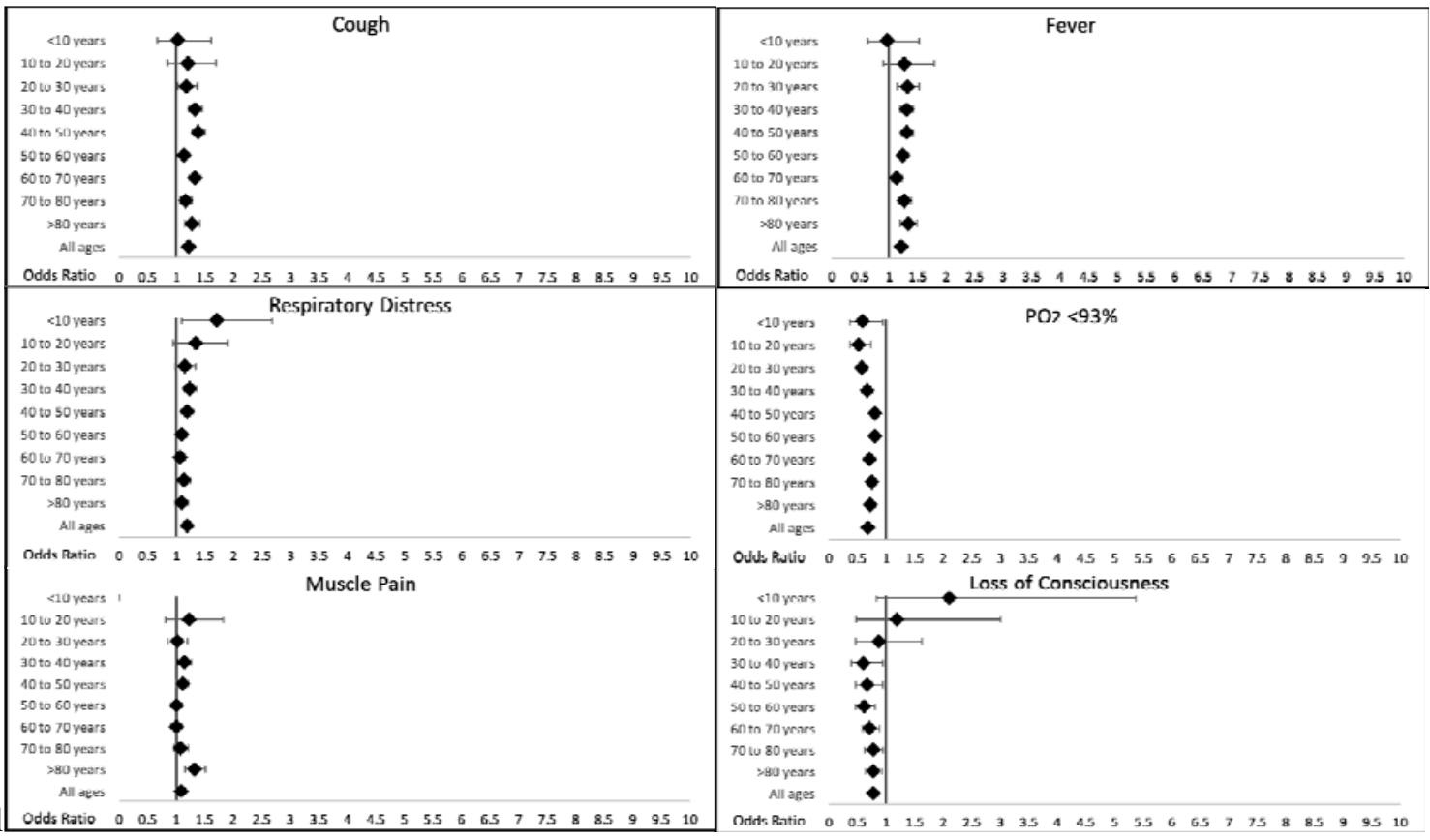

B: Odds ratio for COVID-19 positive vs negative patients of presenting comorbidities by age groups and overall

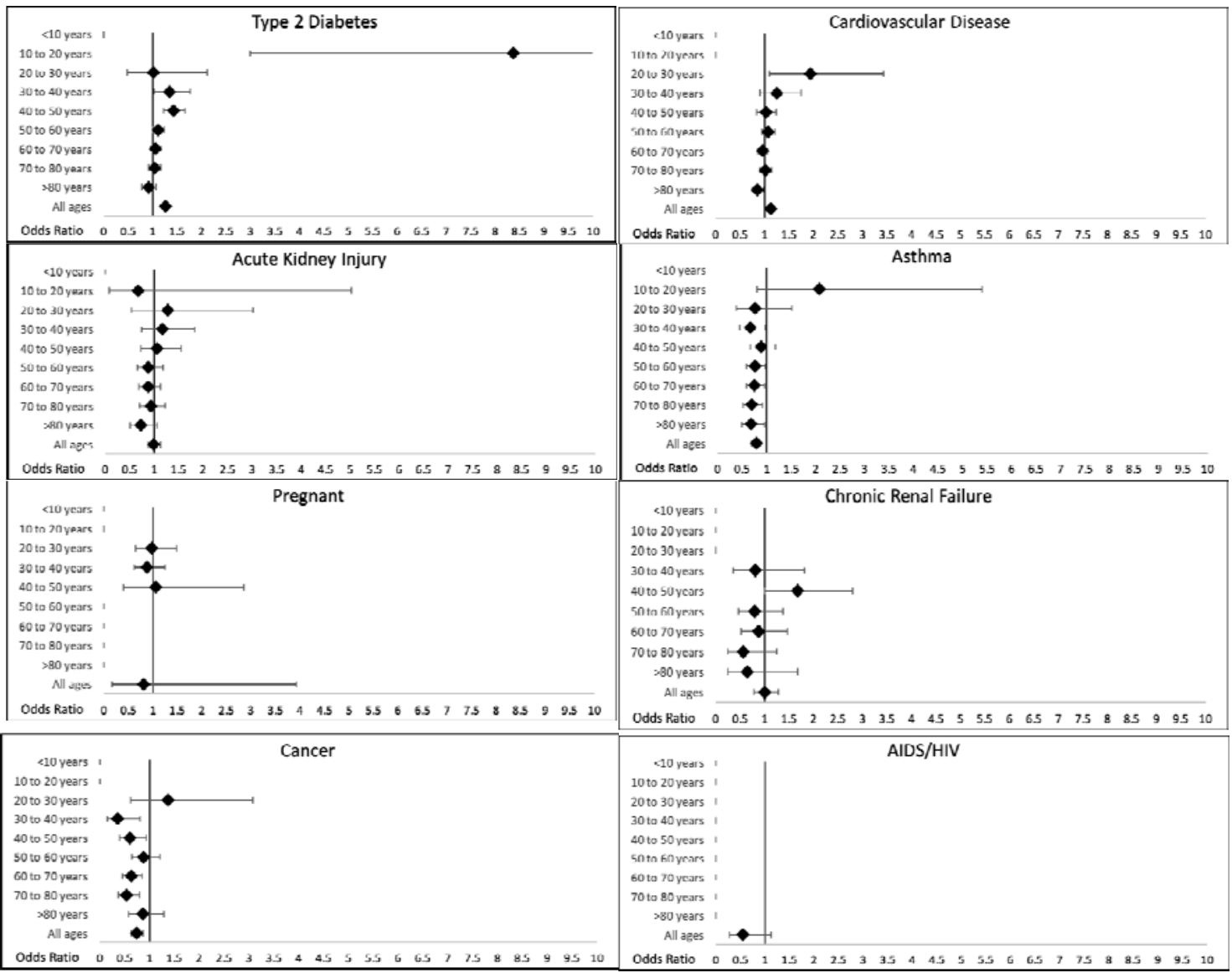


medRxiv preprint doi: https://doi.org/10.1101/2020.04.29.20085233; this version posted May 5, 2020. The copyright holder for this preprint (which was not certified by peer review) is the author/funder, who has granted medRxiv a license to display the preprint in perpetuity. All rights reserved. No reuse allowed without permission.

Figure 2: Percentage and odds ratio for intubation and death by COVID-19 results

A: Intubation frequency by age

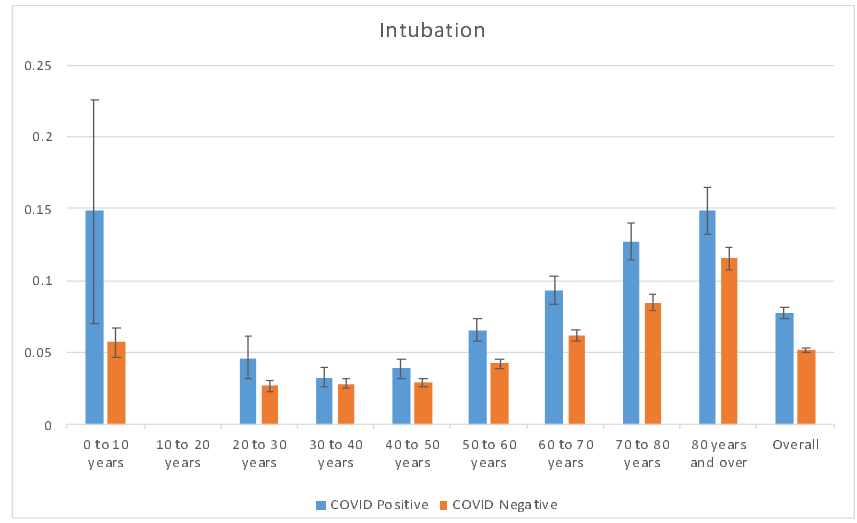

B: Intubation odds ratios by age

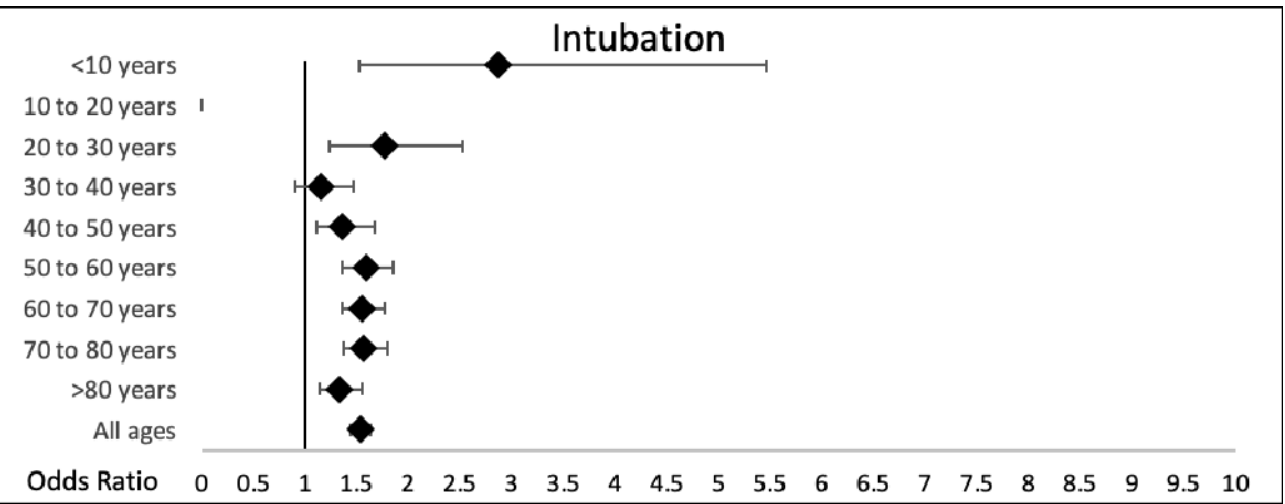

C: Death frequency by age

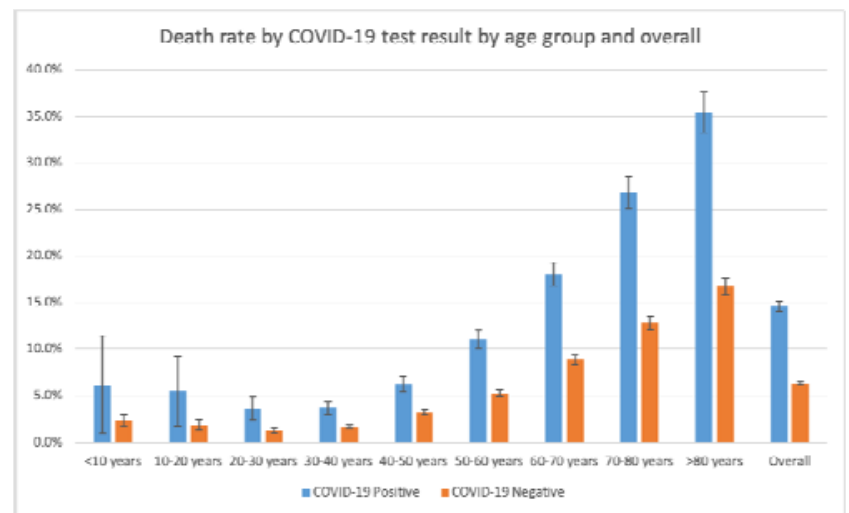

D: Death odds ratios by age

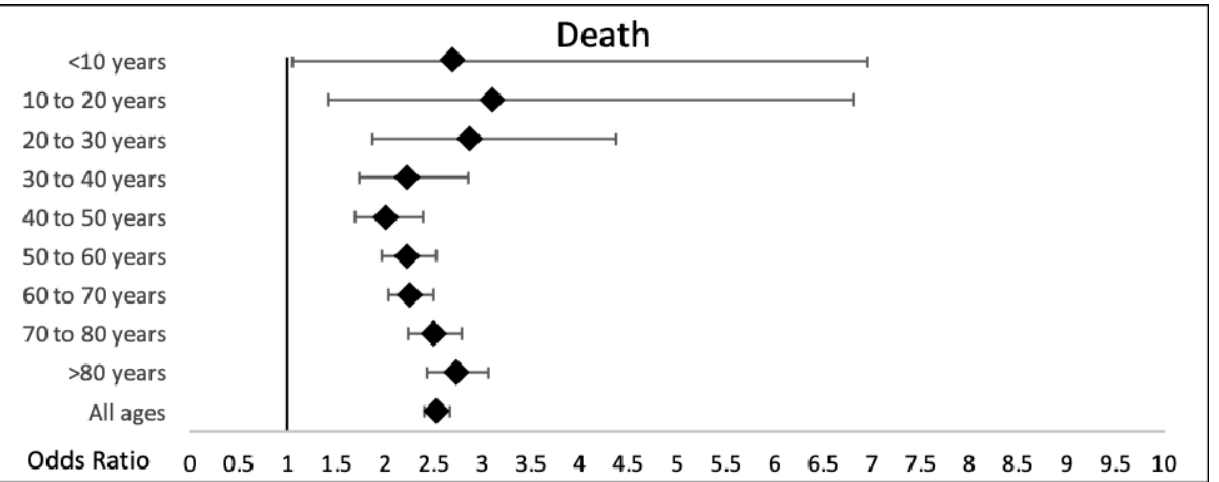


medRxiv preprint doi: https://doi.org/10.1101/2020.04.29.20085233; this version posted May 5, 2020. The copyright holder for this preprint (which was not certified by peer review) is the author/funder, who has granted medRxiv a license to display the preprint in perpetuity.

All rights reserved. No reuse allowed without permission. 
medRxiv preprint doi: https://doi.org/10.1101/2020.04.29.20085233; this version posted May 5, 2020. The copyright holder for this preprint (which was not certified by peer review) is the author/funder, who has granted medRxiv a license to display the preprint in perpetuity. All rights reserved. No reuse allowed without permission.

\section{Supplementary Appendix}

Supplementary Figure 1: Frequency of symptoms and signs by age groups in COVID-19 Positive vs.

Negative patients

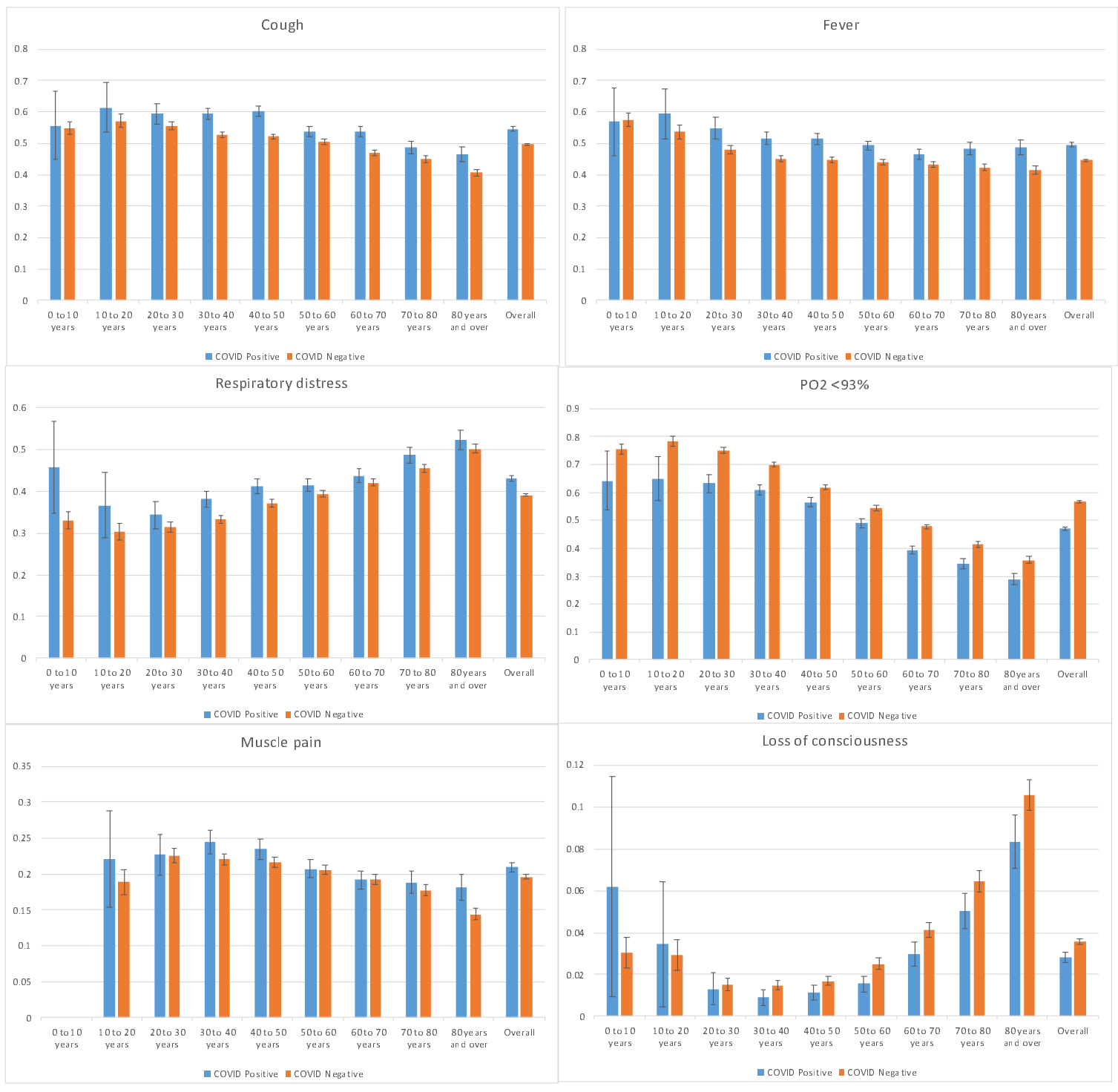


medRxiv preprint doi: https://doi.org/10.1101/2020.04.29.20085233; this version posted May 5, 2020. The copyright holder for this preprint (which was not certified by peer review) is the author/funder, who has granted medRxiv a license to display the preprint in perpetuity.

All rights reserved. No reuse allowed without permission.

Supplementary Figure 2: Frequency of comorbidities by age groups in COVID-19 Positive vs. Negative patients

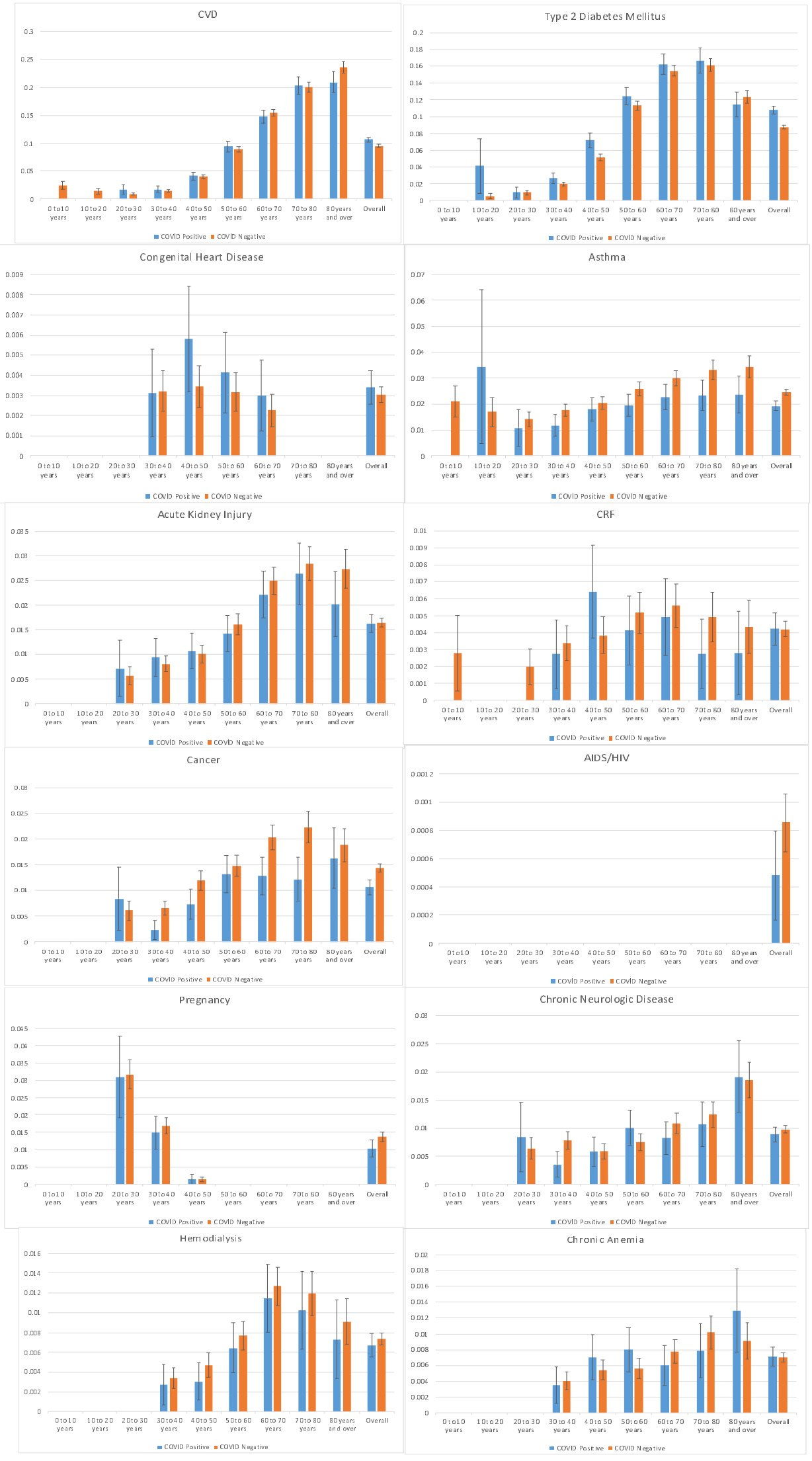


medRxiv preprint doi: https://doi.org/10.1101/2020.04.29.20085233; this version posted May 5, 2020. The copyright holder for this preprint (which was not certified by peer review) is the author/funder, who has granted medRxiv a license to display the preprint in perpetuity.

Supplementary table 1- List of total admission for acute respiratory illness during designated month in 31 provinces of Iran and the change in number of admissions between 2 days to one day prior to the completion of the study

\begin{tabular}{|c|c|c|c|c|c|c|}
\hline Province & $\begin{array}{l}\text { Suspicious } \\
\text { cases }\end{array}$ & Outbreak & Hospitalized & $\begin{array}{l}\text { Admitted day- } \\
1\end{array}$ & $\begin{array}{l}\text { Admitted } \\
\text { day-2 }\end{array}$ & Change \\
\hline Qom Province & 4873 & 3.7708 & 1969 & 33 & 91 & -58 \\
\hline Gilan & 8019 & 3.1687 & 848 & 86 & 106 & -20 \\
\hline Semnan & 1877 & 2.6724 & 420 & 37 & 60 & -23 \\
\hline Mazandaran Province & 8038 & 2.4479 & 4498 & 128 & 301 & -173 \\
\hline Golestan province & 4264 & 2.2819 & 1344 & 47 & 56 & -9 \\
\hline Yazd Province & 2278 & 2.0008 & 881 & 50 & 110 & -60 \\
\hline Tehran Province & 22549 & 1.6995 & 8957 & 770 & 805 & -35 \\
\hline Central Province & 2254 & 1.5768 & 646 & 42 & 63 & -21 \\
\hline Qazvin Province & 1884 & 1.4791 & 319 & 42 & 48 & -6 \\
\hline Isfahan province & 6606 & 1.29 & 3351 & 156 & 246 & -90 \\
\hline Zanjan Province & 1230 & 1.1632 & 370 & 58 & 60 & -2 \\
\hline Lorestan Province & 1870 & 1.0621 & 303 & 71 & 68 & 3 \\
\hline Alborz Province & 2637 & 0.9722 & 1051 & 88 & 110 & -22 \\
\hline South Khorasan province & 696 & 0.9052 & 113 & 15 & 36 & -21 \\
\hline Ilam Province & 517 & 0.8911 & 278 & 22 & 18 & 4 \\
\hline Bushehr Province & 959 & 0.8243 & 649 & 15 & 24 & -9 \\
\hline Ardebil province & 987 & 0.7769 & 463 & 30 & 38 & -8 \\
\hline Khorasan Razavi Province & 4584 & 0.7124 & 1218 & 122 & 196 & -74 \\
\hline North Khorasan Province & 612 & 0.7091 & 130 & 15 & 22 & -7 \\
\hline Fars province & 3197 & 0.659 & 668 & 89 & 114 & -25 \\
\hline Hamedan province & 1112 & 0.6324 & 639 & 27 & 55 & -28 \\
\hline East Azerbaijan Province & 2414 & 0.6174 & 1644 & 77 & 87 & -10 \\
\hline Khuzestan province & 2720 & 0.5774 & 1025 & 75 & 105 & -30 \\
\hline Hormozgan Province & 980 & 0.5517 & 76 & 13 & 24 & -11 \\
\hline Kurdistan province & 809 & 0.5047 & 182 & 24 & 34 & -10 \\
\hline Kermanshah province & 905 & 0.4635 & 204 & 18 & 35 & -17 \\
\hline West Azerbaijan Province & 1416 & 0.4337 & 386 & 78 & 64 & 14 \\
\hline Kerman province & 1356 & 0.4285 & 281 & 45 & 39 & 6 \\
\hline $\begin{array}{l}\text { Chahar Mahal Bakhtiari } \\
\text { Province }\end{array}$ & 386 & 0.4073 & 69 & 10 & 13 & -3 \\
\hline Sistan and Baluchestan Province & 1051 & 0.3787 & 181 & 28 & 29 & -1 \\
\hline $\begin{array}{l}\text { Kohkiluyeh and Boyer Ahmad } \\
\text { Province }\end{array}$ & 219 & 0.3071 & 100 & 4 & 7 & -3 \\
\hline Total & 93299 & 36.3658 & 33263 & 2315 & 3064 & -749 \\
\hline
\end{tabular}




\begin{tabular}{|c|c|c|c|c|}
\hline \multicolumn{5}{|l|}{ A: Cough } \\
\hline Age Groups & $\begin{array}{l}\% \text { among positive } \\
\text { cases }\end{array}$ & $\begin{array}{l}\% \text { among negative } \\
\text { cases }\end{array}$ & Odds Ratio (95\% CI) & p-value \\
\hline$<10$ years & $55.6 \%$ & $54.8 \%$ & $1.03(0.66,1.61)$ & 0.897 \\
\hline 10 to 20 years & $61.4 \%$ & $57.1 \%$ & $1.19(0.84,1.69)$ & 0.315 \\
\hline 20 to 30 years & $59.4 \%$ & $55.4 \%$ & $1.18(1.02,1.36)$ & 0.030 \\
\hline 30 to 40 years & $59.3 \%$ & $52.5 \%$ & $1.32(1.21,1.44)$ & 0.000 \\
\hline 40 to 50 years & $60.1 \%$ & $52.1 \%$ & $1.38(1.28,1.50)$ & 0.000 \\
\hline 50 to 60 years & $53.6 \%$ & $50.5 \%$ & $1.13(1.06,1.22)$ & 0.001 \\
\hline 60 to 70 years & $53.7 \%$ & $46.8 \%$ & $1.32(1.23,1.42)$ & 0.000 \\
\hline 70 to 80 years & $48.7 \%$ & $45.0 \%$ & $1.16(1.06,1.27)$ & 0.001 \\
\hline$>80$ years & $46.4 \%$ & $40.6 \%$ & $1.27(1.14,1.41)$ & 0.000 \\
\hline All ages & $54.5 \%$ & $49.7 \%$ & $1.21(1.18,1.25)$ & 0.000 \\
\hline \multicolumn{5}{|l|}{ B: Fever } \\
\hline Age Groups & $\begin{array}{l}\% \text { among positive } \\
\text { cases }\end{array}$ & $\begin{array}{l}\% \text { among negative } \\
\text { cases }\end{array}$ & Odds Ratio (95\% CI) & p-value \\
\hline$<10$ years & $56.8 \%$ & $57.4 \%$ & $0.97(0.62,1.52)$ & 0.907 \\
\hline 10 to 20 years & $59.3 \%$ & $53.6 \%$ & $1.26(0.90,1.78)$ & 0.181 \\
\hline 20 to 30 years & $54.8 \%$ & $47.9 \%$ & $1.32(1.14,1.52)$ & 0.000 \\
\hline 30 to 40 years & $51.7 \%$ & $45.0 \%$ & $1.31(1.20,1.42)$ & 0.000 \\
\hline 40 to 50 years & $51.4 \%$ & $44.6 \%$ & $1.31(1.21,1.42)$ & 0.000 \\
\hline 50 to 60 years & $49.2 \%$ & $43.9 \%$ & $1.24(1.15,1.33)$ & 0.000 \\
\hline 60 to 70 years & $46.4 \%$ & $43.3 \%$ & $1.13(1.05,1.22)$ & 0.001 \\
\hline 70 to 80 years & $48.2 \%$ & $42.3 \%$ & $1.27(1.16,1.38)$ & 0.000 \\
\hline$>80$ years & $48.6 \%$ & $41.4 \%$ & $1.34(1.20,1.48)$ & 0.000 \\
\hline All ages & $49.5 \%$ & $44.7 \%$ & $1.22(1.18,1.26)$ & 0.000 \\
\hline \multicolumn{5}{|l|}{ C: Intubation } \\
\hline Age Groups & $\begin{array}{l}\% \text { among positive } \\
\text { cases }\end{array}$ & $\begin{array}{l}\% \text { among negative } \\
\text { cases }\end{array}$ & Odds Ratio (95\% CI) & p-value* \\
\hline$<10$ years & $14.8 \%$ & $5.7 \%$ & $2.88(1.52,5.46)$ & 0.001 \\
\hline \multicolumn{5}{|l|}{10 to 20 years } \\
\hline 20 to 30 years & $4.7 \%$ & $2.7 \%$ & $1.77(1.24,2.52)$ & 0.001 \\
\hline 30 to 40 years & $3.3 \%$ & $2.9 \%$ & $1.15(0.91,1.47)$ & 0.244 \\
\hline 40 to 50 years & $3.9 \%$ & $2.9 \%$ & $1.36(1.11,1.68)$ & 0.003 \\
\hline 50 to 60 years & $6.5 \%$ & $4.2 \%$ & $1.59(1.36,1.85)$ & 0.000 \\
\hline 60 to 70 years & $9.3 \%$ & $6.2 \%$ & $1.55(1.36,1.77)$ & 0.000 \\
\hline
\end{tabular}


medRxiv preprint doi: https://doi.org/10.1101/2020.04.29.20085233; this version posted May 5, 2020. The copyright holder for this preprint (which was not certified by peer review) is the author/funder, who has granted medRxiv a license to display the preprint in perpetuity.

All rights reserved. No reuse allowed without permission.

\begin{tabular}{|c|c|c|c|c|}
\hline 70 to 80 years & $12.7 \%$ & $8.5 \%$ & $1.57(1.37,1.80)$ & 0.000 \\
\hline$>80$ years & $14.8 \%$ & $11.6 \%$ & $1.33(1.15,1.55)$ & 0.000 \\
\hline All ages & $7.7 \%$ & $5.2 \%$ & $1.54(1.44,1.64)$ & 0.000 \\
\hline \multicolumn{5}{|l|}{ D: $\mathrm{PO} 2<93 \%$} \\
\hline Age Groups & $\begin{array}{l}\% \text { among positive } \\
\text { cases }\end{array}$ & $\begin{array}{l}\% \text { among negative } \\
\text { cases }\end{array}$ & Odds Ratio $(95 \% \mathrm{CI})$ & p-value \\
\hline$<10$ years & $64.2 \%$ & $75.3 \%$ & $0.59(0.37,0.94)$ & 0.024 \\
\hline 10 to 20 years & $64.8 \%$ & $78.1 \%$ & $0.52(0.36,0.74)$ & 0.000 \\
\hline 20 to 30 years & $63.2 \%$ & $75.0 \%$ & $0.57(0.49,0.67)$ & 0.000 \\
\hline 30 to 40 years & $60.9 \%$ & $69.9 \%$ & $0.67(0.61,0.73)$ & 0.000 \\
\hline 40 to 50 years & $56.4 \%$ & $61.7 \%$ & $0.80(0.74,0.87)$ & 0.000 \\
\hline 50 to 60 years & $48.9 \%$ & $54.3 \%$ & $0.80(0.75,0.86)$ & 0.000 \\
\hline 60 to 70 years & $39.3 \%$ & $47.7 \%$ & $0.71(0.66,0.76)$ & 0.000 \\
\hline 70 to 80 years & $34.5 \%$ & $41.2 \%$ & $0.75(0.69,0.82)$ & 0.000 \\
\hline$>80$ years & $28.9 \%$ & $35.9 \%$ & $0.73(0.65,0.81)$ & 0.000 \\
\hline All ages & $46.9 \%$ & $56.7 \%$ & $0.68(0.66,0.70)$ & 0.000 \\
\hline \multicolumn{5}{|c|}{ E: Reduced Levels of consciousness } \\
\hline Age Groups & $\begin{array}{l}\% \text { among positive } \\
\text { cases }\end{array}$ & $\begin{array}{l}\% \text { among negative } \\
\text { cases }\end{array}$ & Odds Ratio $(95 \% \mathrm{CI})$ & p-value* \\
\hline$<10$ years & $6.2 \%$ & $3.0 \%$ & $2.10(0.82,5.37)$ & 0.109 \\
\hline 10 to 20 years & $3.4 \%$ & $2.9 \%$ & $1.19(0.47,3.01)$ & 0.615 \\
\hline 20 to 30 years & $1.3 \%$ & $1.5 \%$ & $0.87(0.46,1.63)$ & 0.659 \\
\hline 30 to 40 years & $0.9 \%$ & $1.5 \%$ & $0.60(0.39,0.93)$ & 0.022 \\
\hline 40 to 50 years & $1.1 \%$ & $1.7 \%$ & $0.66(0.47,0.94)$ & 0.021 \\
\hline 50 to 60 years & $1.5 \%$ & $2.5 \%$ & $0.61(0.46,0.81)$ & 0.000 \\
\hline 60 to 70 years & $3.0 \%$ & $4.1 \%$ & $0.71(0.58,0.88)$ & 0.001 \\
\hline 70 to 80 years & $5.0 \%$ & $6.5 \%$ & $0.77(0.63,0.94)$ & 0.008 \\
\hline$>80$ years & $8.3 \%$ & $10.5 \%$ & $0.77(0.64,0.93)$ & 0.006 \\
\hline All ages & $2.8 \%$ & $3.6 \%$ & $0.78(0.71,0.86)$ & 0.000 \\
\hline \multicolumn{5}{|l|}{$\begin{array}{l}\text { F: Respiratory } \\
\text { distress }\end{array}$} \\
\hline Age Groups & $\begin{array}{l}\% \text { among positive } \\
\text { cases }\end{array}$ & $\begin{array}{l}\% \text { among negative } \\
\text { cases }\end{array}$ & Odds Ratio $(95 \% \mathrm{CI})$ & p-value \\
\hline$<10$ years & $45.7 \%$ & $32.9 \%$ & $1.71(1.10,2.67)$ & 0.017 \\
\hline 10 to 20 years & $36.6 \%$ & $30.2 \%$ & $1.33(0.94,1.90)$ & 0.108 \\
\hline 20 to 30 years & $34.3 \%$ & $31.4 \%$ & $1.14(0.98,1.33)$ & 0.086 \\
\hline 30 to 40 years & $38.0 \%$ & $33.3 \%$ & $1.23(1.13,1.34)$ & 0.000 \\
\hline
\end{tabular}


medRxiv preprint doi: https://doi.org/10.1101/2020.04.29.20085233; this version posted May 5, 2020. The copyright holder for this preprint (which was not certified by peer review) is the author/funder, who has granted medRxiv a license to display the preprint in perpetuity. All rights reserved. No reuse allowed without permission.

\begin{tabular}{|c|c|c|c|c|}
\hline 40 to 50 years & $41.1 \%$ & $37.1 \%$ & $1.19(1.10,1.28)$ & 0.000 \\
\hline 50 to 60 years & $41.4 \%$ & $39.3 \%$ & $1.09(1.01,1.17)$ & 0.018 \\
\hline 60 to 70 years & $43.6 \%$ & $42.0 \%$ & $1.07(0.99,1.15)$ & 0.081 \\
\hline 70 to 80 years & $48.6 \%$ & $45.4 \%$ & $1.14(1.04,1.24)$ & 0.004 \\
\hline$>80$ years & $52.2 \%$ & $50.1 \%$ & $1.08(0.98,1.20)$ & 0.131 \\
\hline All ages & $43.0 \%$ & $39.0 \%$ & $1.18(1.14,1.22)$ & 0.000 \\
\hline \multicolumn{5}{|l|}{ G: Myalgia } \\
\hline Age Groups & $\begin{array}{l}\% \text { among positive } \\
\text { cases }\end{array}$ & $\begin{array}{l}\% \text { among negative } \\
\text { cases }\end{array}$ & Odds Ratio (95\% CI) & p-value* \\
\hline \multicolumn{5}{|l|}{$<10$ years } \\
\hline 10 to 20 years & $22.1 \%$ & $18.9 \%$ & $1.22(0.81,1.83)$ & 0.346 \\
\hline 20 to 30 years & $22.7 \%$ & $22.5 \%$ & $1.01(0.85,1.20)$ & 0.915 \\
\hline 30 to 40 years & $24.4 \%$ & $22.0 \%$ & $1.14(1.03,1.26)$ & 0.009 \\
\hline 40 to 50 years & $23.4 \%$ & $21.6 \%$ & $1.11(1.01,1.21)$ & 0.027 \\
\hline 50 to 60 years & $20.7 \%$ & $20.6 \%$ & $1.01(0.92,1.10)$ & 0.880 \\
\hline 60 to 70 years & $19.2 \%$ & $19.2 \%$ & $1.00(0.91,1.10)$ & 0.985 \\
\hline 70 to 80 years & $18.8 \%$ & $17.7 \%$ & $1.08(0.96,1.21)$ & 0.195 \\
\hline$>80$ years & $18.2 \%$ & $14.4 \%$ & $1.32(1.15,1.51)$ & 0.000 \\
\hline All ages & $20.9 \%$ & $19.6 \%$ & $1.08(1.04,1.13)$ & 0.000 \\
\hline
\end{tabular}

* Note: where there were cells with $<10$ counts the Fisher Exact test was used, all other tests are $\chi 2$. 
medRxiv preprint doi: https://doi.org/10.1101/2020.04.29.20085233; this version posted May 5, 2020. The copyright holder for this preprint (which was not certified by peer review) is the author/funder, who has granted medRxiv a license to display the preprint in perpetuity.

All rights reserved. No reuse allowed without permission.

Supplement Table 3: Percent, odds ratio, p-values for comorbidities by COVID-19 testing results

\begin{tabular}{|c|c|c|c|c|}
\hline \multicolumn{5}{|l|}{ A: Asthma } \\
\hline Age Groups & $\%$ among positive cases & $\begin{array}{l}\% \text { among negative } \\
\text { cases }\end{array}$ & Odds Ratio (95\% CI) & p-value* \\
\hline \multicolumn{5}{|l|}{$<10$ years } \\
\hline 10 to 20 years & $3.4 \%$ & $1.7 \%$ & $2.07(0.80,5.39)$ & 0.180 \\
\hline 20 to 30 years & $1.1 \%$ & $1.4 \%$ & $0.76(0.38,1.52)$ & 0.530 \\
\hline 30 to 40 years & $1.2 \%$ & $1.8 \%$ & $0.66(0.45,0.97)$ & 0.034 \\
\hline 40 to 50 years & $1.8 \%$ & $2.0 \%$ & $0.88(0.66,1.17)$ & 0.372 \\
\hline 50 to 60 years & $2.0 \%$ & $2.6 \%$ & $0.76(0.59,0.97)$ & 0.028 \\
\hline 60 to 70 years & $2.3 \%$ & $3.0 \%$ & $0.75(0.59,0.95)$ & 0.017 \\
\hline 70 to 80 years & $2.3 \%$ & $3.3 \%$ & $0.69(0.52,0.92)$ & 0.010 \\
\hline$>80$ years & $2.4 \%$ & $3.4 \%$ & $0.68(0.49,0.95)$ & 0.022 \\
\hline All ages & $1.9 \%$ & $2.5 \%$ & $0.78(0.70,0.88)$ & 0.000 \\
\hline \multicolumn{5}{|l|}{ B: Pregnant } \\
\hline Age Groups & $\%$ among positive cases & $\begin{array}{l}\% \text { among negative } \\
\text { cases }\end{array}$ & Odds Ratio (95\% CI) & alue* \\
\hline \multicolumn{5}{|l|}{$<10$ years } \\
\hline \multicolumn{5}{|l|}{10 to 20 years } \\
\hline 20 to 30 years & $3.1 \%$ & $3.2 \%$ & $0.98(0.65,1.48)$ & 0.917 \\
\hline 30 to 40 years & $1.5 \%$ & $1.7 \%$ & $0.88(0.62,1.25)$ & 0.484 \\
\hline 40 to 50 years & $0.2 \%$ & $0.1 \%$ & $1.06(0.39,2.86)$ & 0.802 \\
\hline \multicolumn{5}{|l|}{50 to 60 years } \\
\hline \multicolumn{5}{|l|}{60 to 70 years } \\
\hline \multicolumn{5}{|l|}{70 to 80 years } \\
\hline \multicolumn{5}{|l|}{$>80$ years } \\
\hline All ages & $0.4 \%$ & $0.6 \%$ & $0.81(0.17,3.92)$ & 0.001 \\
\hline \multicolumn{5}{|c|}{ C: Cardiovascular Disease } \\
\hline Age Groups & $\%$ among positive cases & $\begin{array}{l}\% \text { among negative } \\
\text { cases }\end{array}$ & Odds Ratio $(95 \% \mathrm{CI})$ & p-value* \\
\hline \multicolumn{5}{|l|}{$<10$ years } \\
\hline \multicolumn{5}{|l|}{10 to 20 years } \\
\hline 20 to 30 years & $1.8 \%$ & $0.9 \%$ & $1.94(1.10,3.43)$ & 0.020 \\
\hline 30 to 40 years & $1.8 \%$ & $1.4 \%$ & $1.25(0.90,1.74)$ & 0.176 \\
\hline 40 to 50 years & $4.2 \%$ & $4.1 \%$ & $1.02(0.84,1.24)$ & 0.814 \\
\hline 50 to 60 years & $9.4 \%$ & $8.9 \%$ & $1.07(0.94,1.21)$ & 0.302 \\
\hline 60 to 70 years & $14.8 \%$ & $15.4 \%$ & $0.95(0.86,1.06)$ & 0.379 \\
\hline
\end{tabular}


medRxiv preprint doi: https://doi.org/10.1101/2020.04.29.20085233; this version posted May 5, 2020. The copyright holder for this preprint (which was not certified by peer review) is the author/funder, who has granted medRxiv a license to display the preprint in perpetuity. All rights reserved. No reuse allowed without permission.

\begin{tabular}{|l|l|l|l|l|}
\hline 70 to 80 years & $20.3 \%$ & $20.0 \%$ & $1.02(0.91,1.13)$ & 0.776 \\
\hline$>80$ years & $20.9 \%$ & $23.5 \%$ & $0.86(0.76,0.97)$ & 0.019 \\
\hline All ages & $10.6 \%$ & $9.5 \%$ & $1.13(1.07,1.19)$ & 0.000 \\
\hline D: Chronic Renal & & & &
\end{tabular}

Failure

\begin{tabular}{|c|c|c|c|c|}
\hline Age Groups & $\%$ among positive cases & $\begin{array}{l}\% \text { among negative } \\
\text { cases }\end{array}$ & Odds Ratio (95\% CI) & p-value* \\
\hline \multicolumn{5}{|l|}{$<10$ years } \\
\hline \multicolumn{5}{|l|}{10 to 20 years } \\
\hline \multicolumn{5}{|l|}{20 to 30 years } \\
\hline 30 to 40 years & $0.3 \%$ & $0.3 \%$ & $0.81(0.36,1.81)$ & 0.706 \\
\hline 40 to 50 years & $0.6 \%$ & $0.4 \%$ & $1.68(1.00,2.80)$ & 0.047 \\
\hline 50 to 60 years & $0.4 \%$ & $0.5 \%$ & $0.80(0.46,1.37)$ & 0.414 \\
\hline 60 to 70 years & $0.5 \%$ & $0.6 \%$ & $0.88(0.52,1.47)$ & 0.623 \\
\hline 70 to 80 years & $0.3 \%$ & $0.5 \%$ & $0.56(0.25,1.24)$ & 0.177 \\
\hline$>80$ years & $0.3 \%$ & $0.4 \%$ & $0.65(0.25,1.68)$ & 0.526 \\
\hline All ages & $0.4 \%$ & $0.4 \%$ & $1.00(0.78,1.28)$ & 0.984 \\
\hline \multicolumn{5}{|c|}{ E: Chronic anemia } \\
\hline Age Groups & $\%$ among positive cases & $\begin{array}{l}\% \text { among negative } \\
\text { cases }\end{array}$ & Odds Ratio (95\% CI) & p-value* \\
\hline \multicolumn{5}{|l|}{$<10$ years } \\
\hline \multicolumn{5}{|l|}{10 to 20 years } \\
\hline \multicolumn{5}{|l|}{20 to 30 years } \\
\hline 30 to 40 years & $0.4 \%$ & $0.4 \%$ & $0.87(0.43,1.78)$ & 0.862 \\
\hline 40 to 50 years & $0.7 \%$ & $0.5 \%$ & $1.29(0.81,2.08)$ & 0.286 \\
\hline 50 to 60 years & $0.8 \%$ & $0.6 \%$ & $1.43(0.94,2.17)$ & 0.094 \\
\hline 60 to 70 years & $0.6 \%$ & $0.8 \%$ & $0.77(0.49,1.23)$ & 0.272 \\
\hline 70 to 80 years & $0.8 \%$ & $1.0 \%$ & $0.77(0.48,1.26)$ & 0.296 \\
\hline$>80$ years & $1.3 \%$ & $0.9 \%$ & $1.42(0.88,2.31)$ & 0.149 \\
\hline All ages & $0.7 \%$ & $0.7 \%$ & $1.02(0.84,1.23)$ & 0.869 \\
\hline \multicolumn{5}{|c|}{ F: Acute Kidney Injury } \\
\hline Age Groups & $\%$ among positive cases & $\begin{array}{l}\% \text { among negative } \\
\text { cases }\end{array}$ & Odds Ratio (95\% CI) & p-value* \\
\hline \multicolumn{5}{|l|}{$<10$ years } \\
\hline 10 to 20 years & $0.7 \%$ & $1.0 \%$ & $0.67(0.09,5.03)$ & 1.000 \\
\hline 20 to 30 years & $0.7 \%$ & $0.6 \%$ & $1.27(0.54,3.02)$ & 0.626 \\
\hline 30 to 40 years & $0.9 \%$ & $0.8 \%$ & $1.16(0.74,1.82)$ & 0.505 \\
\hline
\end{tabular}


medRxiv preprint doi: https://doi.org/10.1101/2020.04.29.20085233; this version posted May 5, 2020. The copyright holder for this preprint (which was not certified by peer review) is the author/funder, who has granted medRxiv a license to display the preprint in perpetuity.

All rights reserved. No reuse allowed without permission.

\begin{tabular}{|c|c|c|c|c|}
\hline 40 to 50 years & $1.1 \%$ & $1.0 \%$ & $1.06(0.73,1.55)$ & 0.756 \\
\hline 50 to 60 years & $1.4 \%$ & $1.6 \%$ & $0.88(0.65,1.18)$ & 0.398 \\
\hline 60 to 70 years & $2.2 \%$ & $2.5 \%$ & $0.88(0.69,1.13)$ & 0.329 \\
\hline 70 to 80 years & $2.6 \%$ & $2.8 \%$ & $0.93(0.71,1.22)$ & 0.587 \\
\hline$>80$ years & $2.0 \%$ & $2.7 \%$ & $0.73(0.51,1.05)$ & 0.093 \\
\hline All ages & $1.6 \%$ & $1.6 \%$ & $0.99(0.88,1.13)$ & 0.931 \\
\hline \multicolumn{5}{|l|}{ G: Cancer } \\
\hline Age Groups & $\%$ among positive cases & $\begin{array}{l}\% \text { among negative } \\
\text { cases }\end{array}$ & Odds Ratio (95\% CI) & p-value \\
\hline \multicolumn{5}{|l|}{$<10$ years } \\
\hline \multicolumn{5}{|l|}{10 to 20 years } \\
\hline 20 to 30 years & $0.8 \%$ & $0.6 \%$ & $1.37(0.61,3.08)$ & 0.480 \\
\hline 30 to 40 years & $0.2 \%$ & $0.7 \%$ & $0.35(0.15,0.81)$ & 0.009 \\
\hline 40 to 50 years & $0.7 \%$ & $1.2 \%$ & $0.61(0.39,0.94)$ & 0.023 \\
\hline 50 to 60 years & $1.3 \%$ & $1.5 \%$ & $0.88(0.65,1.21)$ & 0.437 \\
\hline 60 to 70 years & $1.3 \%$ & $2.0 \%$ & $0.63(0.46,0.86)$ & 0.003 \\
\hline 70 to 80 years & $1.2 \%$ & $2.2 \%$ & $0.54(0.37,0.79)$ & 0.001 \\
\hline$>80$ years & $1.6 \%$ & $1.9 \%$ & $0.86(0.57,1.30)$ & 0.480 \\
\hline All ages & $1.1 \%$ & $1.4 \%$ & $0.74(0.64,0.86)$ & 0.000 \\
\hline
\end{tabular}

H: Type 2 diabetes mellitus

\begin{tabular}{|c|c|c|c|c|}
\hline Age Groups & $\%$ among positive cases & $\begin{array}{l}\% \text { among negative } \\
\text { cases }\end{array}$ & Odds Ratio (95\% CI) & p-value* \\
\hline \multicolumn{5}{|l|}{$<10$ years } \\
\hline 10 to 20 years & $4.1 \%$ & $0.5 \%$ & $8.37(3.00,23.37)$ & $<0.001$ \\
\hline 20 to 30 years & $1.0 \%$ & $0.9 \%$ & $1.01(0.48,2.12)$ & 1.000 \\
\hline 30 to 40 years & $2.7 \%$ & $2.0 \%$ & $1.34(1.02,1.76)$ & 0.033 \\
\hline 40 to 50 years & $7.2 \%$ & $5.1 \%$ & $1.43(1.22,1.67)$ & 0.000 \\
\hline 50 to 60 years & $12.4 \%$ & $11.3 \%$ & $1.11(1.00,1.24)$ & 0.055 \\
\hline 60 to 70 years & $16.2 \%$ & $15.4 \%$ & $1.06(0.96,1.17)$ & 0.253 \\
\hline 70 to 80 years & $16.7 \%$ & $16.2 \%$ & $1.04(0.92,1.17)$ & 0.541 \\
\hline$>80$ years & $11.4 \%$ & $12.3 \%$ & $0.91(0.78,1.08)$ & 0.285 \\
\hline All ages & $10.8 \%$ & $8.7 \%$ & $1.26(1.20,1.33)$ & 0.000 \\
\hline \multicolumn{5}{|c|}{ I: Chronic neurologic disease } \\
\hline Age Groups & $\%$ among positive cases & $\begin{array}{l}\% \text { among negative } \\
\text { cases }\end{array}$ & Odds Ratio $(95 \% \mathrm{CI})$ & p-value* \\
\hline$<10$ years & $1.2 \%$ & $1.9 \%$ & $0.66(0.09,4.84)$ & 1.000 \\
\hline 10 to 20 years & $0.7 \%$ & $1.5 \%$ & $0.46(0.06,3.40)$ & 0.718 \\
\hline
\end{tabular}


medRxiv preprint doi: https://doi.org/10.1101/2020.04.29.20085233; this version posted May 5, 2020. The copyright holder for this preprint (which was not certified by peer review) is the author/funder, who has granted medRxiv a license to display the preprint in perpetuity.

All rights reserved. No reuse allowed without permission.

\begin{tabular}{|c|c|c|c|c|}
\hline 20 to 30 years & $0.8 \%$ & $0.6 \%$ & $1.31(0.59,2.92)$ & 0.495 \\
\hline 30 to 40 years & $0.4 \%$ & $0.8 \%$ & $0.45(0.23,0.89)$ & 0.019 \\
\hline 40 to 50 years & $0.6 \%$ & $0.6 \%$ & $0.98(0.59,1.63)$ & 0.939 \\
\hline 50 to 60 years & $1.0 \%$ & $0.8 \%$ & $1.34(0.92,1.94)$ & 0.122 \\
\hline 60 to 70 years & $0.8 \%$ & $1.1 \%$ & $0.76(0.51,1.12)$ & 0.167 \\
\hline 70 to 80 years & $1.1 \%$ & $1.2 \%$ & $0.86(0.56,1.31)$ & 0.468 \\
\hline$>80$ years & $1.9 \%$ & $1.9 \%$ & $1.03(0.70,1.51)$ & 0.872 \\
\hline All ages & $0.9 \%$ & $1.0 \%$ & $0.91(0.77,1.08)$ & 0.274 \\
\hline $\begin{array}{l}\text { J: AIDS or HI } \\
\text { Age Groups }\end{array}$ & $\%$ among positive cases & $\begin{array}{l}\% \text { among negative } \\
\text { cases }\end{array}$ & Odds Ratio (95\% CI) & p-value* \\
\hline \multicolumn{5}{|l|}{$<10$ years } \\
\hline \multicolumn{5}{|l|}{10 to 20 years } \\
\hline \multicolumn{5}{|l|}{20 to 30 years } \\
\hline \multicolumn{5}{|l|}{30 to 40 years } \\
\hline \multicolumn{5}{|l|}{40 to 50 years } \\
\hline \multicolumn{5}{|l|}{50 to 60 years } \\
\hline \multicolumn{5}{|l|}{60 to 70 years } \\
\hline \multicolumn{5}{|l|}{70 to 80 years } \\
\hline \multicolumn{5}{|l|}{$>80$ years } \\
\hline All ages & $0.0 \%$ & $0.1 \%$ & $0.56(0.28,1.13)$ & 0.100 \\
\hline \multicolumn{5}{|c|}{$\mathrm{K}$ : Congenital heart disease } \\
\hline Age Groups & $\%$ among positive cases & $\begin{array}{l}\% \text { among negative } \\
\text { cases }\end{array}$ & Odds Ratio (95\% CI) & p-value* \\
\hline \multicolumn{5}{|l|}{$<10$ years } \\
\hline \multicolumn{5}{|l|}{20 to 30 years } \\
\hline 30 to 40 years & $0.3 \%$ & $0.3 \%$ & $0.97(0.45,2.09)$ & 1.000 \\
\hline 40 to 50 years & $0.6 \%$ & $0.3 \%$ & $1.69(0.98,2.91)$ & 0.054 \\
\hline 50 to 60 years & $0.4 \%$ & $0.3 \%$ & $1.30(0.73,2.31)$ & 0.369 \\
\hline 60 to 70 years & $0.3 \%$ & $0.2 \%$ & $1.33(0.67,2.67)$ & 0.414 \\
\hline 70 to 80 years & $0.2 \%$ & $0.2 \%$ & $1.01(0.33,3.06)$ & 1.000 \\
\hline$>80$ years & $0.1 \%$ & $0.2 \%$ & $0.27(0.04,2.04)$ & 0.220 \\
\hline All ages & $0.3 \%$ & $0.3 \%$ & $1.12(0.85,1.48)$ & 0.426 \\
\hline \multicolumn{5}{|c|}{ L: Hemodialysis } \\
\hline Age Groups & $\%$ among positive cases & $\begin{array}{l}\% \text { among negative } \\
\text { cases }\end{array}$ & Odds Ratio (95\% CI) & p-value* \\
\hline
\end{tabular}


medRxiv preprint doi: https://doi.org/10.1101/2020.04.29.20085233; this version posted May 5, 2020. The copyright holder for this preprint (which was not certified by peer review) is the author/funder, who has granted medRxiv a license to display the preprint in perpetuity.

All rights reserved. No reuse allowed without permission.

\begin{tabular}{|l|l|l|l|l}
\hline$<10$ years & $1.2 \%$ & $0.1 \%$ & $8.92(0.92,86.67)$ & 0.138 \\
\hline 10 to 20 years & $0.7 \%$ & $0.5 \%$ & $1.50(0.19,11.90)$ & 0.513 \\
\hline 20 to 30 years & $0.1 \%$ & $0.4 \%$ & $0.34(0.05,2.52)$ & 0.512 \\
\hline 30 to 40 years & $0.3 \%$ & $0.3 \%$ & $0.81(0.36,1.81)$ & 0.706 \\
40 to 50 years & $0.3 \%$ & $0.5 \%$ & $0.65(0.33,1.26)$ & 0.235 \\
50 to 60 years & $0.6 \%$ & $0.8 \%$ & $0.84(0.54,1.30)$ & 0.430 \\
60 to 70 years & $1.1 \%$ & $1.3 \%$ & $0.90(0.64,1.27)$ & 0.565 \\
70 to 80 years & $1.0 \%$ & $1.2 \%$ & $0.85(0.56,1.31)$ & 0.474 \\
\hline 80 years & $0.7 \%$ & $0.9 \%$ & $0.80(0.44,1.46)$ & 0.466 \\
All ages & $0.7 \%$ & $0.7 \%$ & $0.91(0.75,1.11)$ & 0.346
\end{tabular}

* Note: where there were cells with $<10$ counts the Fisher Exact test was used, all other tests are $\chi 2$. 
medRxiv preprint doi: https://doi.org/10.1101/2020.04.29.20085233; this version posted May 5, 2020. The copyright holder for this preprint (which was not certified by peer review) is the author/funder, who has granted medRxiv a license to display the preprint in perpetuity. All rights reserved. No reuse allowed without permission.

Supplement Table 4: Intubation by age group, including calculations for $\chi^{2}$ testing.

\begin{tabular}{|c|c|c|c|c|c|c|c|c|}
\hline Age Groups & $\begin{array}{c}\text { Total } \\
\text { number }\end{array}$ & $\begin{array}{c}\text { Mean } \\
\text { age }\end{array}$ & Intubation & $\begin{array}{c}\text { No } \\
\text { intubation }\end{array}$ & $\begin{array}{c}\text { Total } \\
\text { number }\end{array}$ & Predicted & Predicted & p-value* \\
\hline$<10$ Positive for COVID-19 & 81 & 3 & 12 & 69 & 81 & 4.880396 & 76.1196 & \\
\hline$<10$ Negative for COVID-19 & 2143 & 3 & 122 & 2021 & 2143 & 129.1196 & 2013.88 & \\
\hline$<10$ all cases & 2224 & 3 & 134 & 2090 & 2224 & & & 0.000707 \\
\hline 10-20 Negative for COVID-19 & 1949 & 15 & 84 & 1865 & 1949 & & & \\
\hline $10-20$ all cases & 2094 & 15 & 88 & 2006 & 2094 & & & $0.518^{*}$ \\
\hline 20-30 Positive for COVID-19 & 837 & 25 & 39 & 798 & 837 & 24.34786 & 812.6521 & \\
\hline 30-40 Positive for COVID-19 & 2553 & 34 & 84 & 2469 & 2553 & 74.96035 & 2478.04 & \\
\hline 30-40 Negative for COVID-19 & 12126 & 34 & 347 & 11779 & 12126 & 356.0396 & 11769.96 & \\
\hline $30-40$ all cases & 14679 & 34 & 431 & 14248 & 14679 & & & 0.243617 \\
\hline 40-50 Positive for COVID-19 & 3274 & 44 & 128 & 3146 & 3274 & 101.677 & 3172.323 & \\
\hline 40-50 Negative for COVID-19 & 12504 & 44 & 362 & 12142 & 12504 & 388.323 & 12115.68 & \\
\hline $40-50$ all cases & 15778 & 44 & 490 & 15288 & 15778 & & & 0.002892 \\
\hline 50-60 Positive for COVID-19 & 3878 & 54 & 254 & 3624 & 3878 & 184.0837 & 3693.916 & \\
\hline 70-80 Positive for COVID-19 & 2543 & 74 & 323 & 2220 & 2543 & 239.4843 & 2303.516 & \\
\hline 70-80 Negative for COVID-19 & 8957 & 73 & 760 & 8197 & 8957 & 843.5157 & 8113.484 & \\
\hline $70-80$ all cases & 11500 & 74 & 1083 & 10417 & 11500 & & & 1.32E-10 \\
\hline 80> Positive for COVID-19 & 1779 & 84 & 264 & 1515 & 1779 & 217.991 & 1561.009 & \\
\hline 80> Negative for COVID-19 & 6692 & 85 & 774 & 5918 & 6692 & 820.009 & 5871.991 & \\
\hline $80>$ all cases & 8471 & 84 & 1038 & 7433 & 8471 & & & 0.000182 \\
\hline Total positive for COVID-19 & 18754 & & 1450 & 17304 & 18754 & 1063.344 & 17690.66 & \\
\hline Total negative for COVID-19 & 77349 & & 3999 & 73350 & 77349 & 4385.656 & 72963.34 & \\
\hline Total & 96103 & & 5449 & 90654 & 96103 & & & 3.57E-42 \\
\hline
\end{tabular}

* Note: where there were cells with $<10$ counts the Fisher Exact test was used, all other tests are $\chi 2$. 
medRxiv preprint doi: https://doi.org/10.1101/2020.04.29.20085233; this version posted May 5, 2020. The copyright holder for this preprint (which was not certified by peer review) is the author/funder, who has granted medRxiv a license to display the preprint in perpetuity.

All rights reserved. No reuse allowed without permission.

Supplement Table 5: Death by age group, including calculations for $\chi^{2}$ testing.

\begin{tabular}{|c|c|c|c|c|c|c|c|c|}
\hline Age Groups & Total & Mean & Death & Live & Total & Predicted & Predicted & p-value* \\
\hline
\end{tabular}


medRxiv preprint doi: https://doi.org/10.1101/2020.04.29.20085233; this version posted May 5, 2020. The copyright holder for this preprint (which was not certified by peer review) is the author/funder, who has granted medRxiv a license to display the preprint in perpetuity.

All rights reserved. No reuse allowed without permission.

\begin{tabular}{|c|c|c|c|c|c|c|c|c|}
\hline & number & age & & & number & & & \\
\hline$<10$ Positive for COVID-19 & 81 & 3 & 5 & 76 & 81 & & & \\
\hline$<10$ Negative for COVID-19 & 2143 & 3 & 51 & 2092 & 2143 & & & \\
\hline$<10$ all cases & 2224 & 3 & 56 & 2168 & 2224 & & & $0.051^{*}$ \\
\hline 10-20 Positive for COVID-19 & 145 & 16 & 8 & 137 & 145 & & & \\
\hline 10-20 Negative for COVID-19 & 1949 & 15 & 36 & 1913 & 1949 & & & \\
\hline $10-20$ all cases & 2094 & 15 & 44 & 2050 & 2094 & & & $0.009 *$ \\
\hline 20-30 Positive for COVID-19 & 837 & 25 & 30 & 807 & 837 & 12.91003 & 824.09 & \\
\hline 20-30 Negative for COVID-19 & 6554 & 25 & 84 & 6470 & 6554 & 101.09 & 6452.91 & \\
\hline 20-30 all cases & 7391 & 25 & 114 & 7277 & 7391 & & & 3.57E-07 \\
\hline 30-40 Positive for COVID-19 & 2553 & 34 & 93 & 2460 & 2553 & 51.48089 & 2501.519 & \\
\hline 30-40 Negative for COVID-19 & 12126 & 34 & 203 & 11923 & 12126 & 244.5191 & 11881.48 & \\
\hline $30-40$ all cases & 14679 & 34 & 296 & 14383 & 14679 & & & $1.26 \mathrm{E}-10$ \\
\hline 40-50 Positive for COVID-19 & 3274 & 44 & 205 & 3069 & 3274 & 125.955 & 3148.045 & \\
\hline 40-50 Negative for COVID-19 & 12504 & 44 & 402 & 12102 & 12504 & 481.045 & 12022.96 & \\
\hline $40-50$ all cases & 15778 & 44 & 607 & 15171 & 15778 & & & 7.12E-16 \\
\hline 50-60 Positive for COVID-19 & 3878 & 54 & 427 & 3451 & 3878 & 253.5324 & 3624.468 & \\
\hline 50-60 Negative for COVID-19 & 13544 & 54 & 712 & 12832 & 13544 & 885.4676 & 12658.53 & \\
\hline $50-60$ all cases & 17422 & 54 & 1139 & 16283 & 17422 & & & 2.1E-37 \\
\hline 60-70 Positive for COVID-19 & 3664 & 64 & 661 & 3003 & 3664 & 400.1963 & 3263.804 & \\
\hline 60-70 Negative for COVID-19 & 12880 & 64 & 1146 & 11734 & 12880 & 1406.804 & 11473.2 & \\
\hline $60-70$ all cases & 16544 & 64 & 1807 & 14737 & 16544 & & & 3.07E-55 \\
\hline 70-80 Positive for COVID-19 & 2543 & 74 & 681 & 1862 & 2543 & 403.563 & 2139.437 & \\
\hline 70-80 Negative for COVID-19 & 8957 & 73 & 1144 & 7813 & 8957 & 1421.437 & 7535.563 & \\
\hline $70-80$ all cases & 11500 & 74 & 1825 & 9675 & 11500 & & & 2.9E-65 \\
\hline 80> Positive for COVID-19 & 1779 & 84 & 630 & 1149 & 1779 & 367.5186 & 1411.481 & \\
\hline $80>$ Negative for COVID-19 & 6692 & 85 & 1120 & 5572 & 6692 & 1382.481 & 5309.519 & \\
\hline $80>$ all cases & 8471 & 84 & 1750 & 6721 & 8471 & & & 5.21E-67 \\
\hline Total positive for COVID-19 & 18754 & & 2740 & 16014 & 18754 & 1490.516 & 17263.48 & \\
\hline Total negative for COVID-19 & 77349 & & 4898 & 72451 & 77349 & 6147.484 & 71201.52 & \\
\hline Total & 96103 & & 7638 & 88465 & 96103 & & & $\mathbf{0}$ \\
\hline
\end{tabular}

Supplement Table 6:Trend in hospital discharge in 31 provinces; 1 and 2 days prior to completion of the study

State

Total discharged Discharged -1 d Discharged -2 d Change 
medRxiv preprint doi: https://doi.org/10.1101/2020.04.29.20085233; this version posted May 5, 2020. The copyright holder for this preprint (which was not certified by peer review) is the author/funder, who has granted medRxiv a license to display the preprint in perpetuity. All rights reserved. No reuse allowed without permission.

\begin{tabular}{|c|c|c|c|c|}
\hline Tehran & 12186 & 271 & 260 & -11 \\
\hline Gilan & 5975 & 15 & 17 & 2 \\
\hline Khorasan Razavi & 2930 & 22 & 70 & 48 \\
\hline Mazandaran & 2842 & 16 & 54 & 38 \\
\hline Esfahan & 2755 & 19 & 29 & 10 \\
\hline Fars & 2502 & 15 & 37 & 22 \\
\hline Golestan & 2374 & 4 & 2 & -2 \\
\hline Qom & 2223 & 8 & 63 & 55 \\
\hline Khuzestan & 1591 & 16 & 36 & 20 \\
\hline Central & 1451 & 5 & 6 & 1 \\
\hline Lorestan & 1450 & 34 & 29 & -5 \\
\hline Qazvin & 1392 & 2 & 8 & 6 \\
\hline Alborz & 1358 & 9 & 21 & 12 \\
\hline Semnan & 1344 & 4 & 19 & 15 \\
\hline Yazd & 1262 & 12 & 1 & -11 \\
\hline Kerman & 993 & 13 & 13 & 0 \\
\hline Western Azerbaijan & 949 & 2 & 8 & 6 \\
\hline Hormozgan & 851 & 1 & 9 & 8 \\
\hline Sistan and Baluchestan & 796 & 1 & 7 & 6 \\
\hline Zanjan & 785 & 9 & 15 & 6 \\
\hline Kermanshah & 653 & 8 & 12 & 4 \\
\hline East Azarbaijan & 636 & 6 & 9 & 3 \\
\hline Kurdistan & 562 & 2 & 3 & 1 \\
\hline southern Khorasan & 548 & NA & 4 & \\
\hline Ardebil & 452 & NA & 4 & \\
\hline Hamedan & 444 & 1 & NA & \\
\hline North Khorasan & 426 & 3 & 3 & 0 \\
\hline Bushehr & 309 & NA & 2 & \\
\hline Chahar Mahal Bakhtiari & 294 & 2 & 6 & 4 \\
\hline Ilam & 221 & 6 & 8 & 2 \\
\hline Kohkiluye and Boyer Ahmad & 112 & 2 & 2 & 0 \\
\hline TOTAL & 52666 & 508 & 757 & 240 \\
\hline
\end{tabular}

